Karahan Kök, Naciye (2020). Türkistan Hanlıklarına Ait Belgelerde Geçen Meslek ve Unvan Adları, Uluslararası Uygur Araştırmaları Dergisi, Sayı: 2020/15, s. 1-30.

DOI: 10.46400/uygur.728108

\title{
TÜRKISTAN HANLIKLARINA AİT BELGELERDE GEÇEN MESLEK VE UNVAN ADLARI
}

[Araștırma Makalesi-Research Article]

$\begin{array}{ccc} & \text { Naciye KARAHAN KÖK } \\ \text { Geliş Tarihi: 27.04.2020 } & & \text { Kabul Tarihi: } 09.05 .2020\end{array}$

Bu çalışmadaTürkistan hanlıkları olarak adlandirılan Buhara (1599-1685), Hive (1704-1920) ve Hokand Hanlıklarına (1710-1876) ait, Farsça ve Doğu Türk yazı diliyle yazılmış belgelerin söz varlı̆̆ından hareketle dönemin sosyal ve kültürel hayatının izleriyle yansımalarınınunvan ve meslekler bağlamında tespit edilmesi amaçlanmıştır. Unvan ve meslek adları tespit edilirkenW.Wood'un2005'te yayınladığı A Collection of Tarkhan Yarlīqs from the Khanate of Khiva, Yuri Bregel'in 1966'da neșrettiği Documents from the Khanate of Khiva, 17-19th centuriesadl çalışmalarıyla Jannatkhon Asqarova'nın Türkistan Hanlıkları Yazışmaları Dil ve Üslup Incelemesi başlıklı yüksek lisans tezinde yeralan soyurgal yarlık, yarlıg-ı 'âlîler ve tarhanlık yarlıklarıyla bitiklerden yararlanılmıştır. Söz konusu çalışmalardaki meslek adlarına geçmeden önce Türkistan hanlıkları diplomatikasındaki yarlık, tarhanlık yarlı̆̆l, soyurgal yarlık, hükm-i 'alî, emr-i 'âlî ve bitik gibi teknik terimler üzerinde durulup ardından bu belgelerdeki unvan ve meslekler uğraşı alanlarına göre bir sinıflandırmaya tabi tutulmuștur. Sinıflandırmaya tabi tutulan her unvan ve meslek adı aynı zamanda yapı ve köken bakımından da incelenerek ilgili ad hakkında topluca bir değerlendirmenin yapılması amaçlanmıştır. Yapı incelemelerindeöncelikle Türkçenin belli başl etimolojik sözlüklerindeki veriler esasalınmıștır. Unvan ve meslek adlarıyla ilgili çok özel bir çalışma varsa ona da değinilmiştir. Morfolojik yapısı şüpheye yer bırakmayacak kadar açık olanlarda herhangi bir kaynağa atıf yapılmamıștır. Unvan ve meslek adlarınınsıralanmasında ise alfabetik sıralama yolu tercih edilmiștir. Çalıșmanın sonunda Türkistan hanlıklarında hangi meslek ve unvanların kullanıldığı, bunların hangi tür gereksinimleri karşıladıkları, meslek ve unvanların Türkistan hanlıklarındaki halk üzerindeki etkisi ve yeriyle kuruluşunda hangi dil kurallarının gözetildiği sorularına cevap aranmaya çalışılmıștır.

Anahtar Kelimeler: Türkistan Hanlıkları, Yarlık, Bitik, Meslekler, Unvanlar.

\section{OCCUPATION AND TITLE NAMES MENTIONED IN THE DOCUMENTS OFTHE TURKISTAN KHANATES}

\begin{abstract}
In this study, it was aimed to determine the traces and reflections of social andcultural life in the Khanate of Bukhara (1599-1685), Khanate of Khiva (17041920), and Khanate of Kohand (1710-1876), which were called as the Turkistan khanates, based on the vocabulary of documents of the khanates written in Persian ad Eastern Turkish languages, within the context of titles and occupations. Occupation and title names were determined using soyurgal yarliq, yarliq-i Ǿâlîler, tarhanlik yarliq and bitiks mentioned in A Collection of Tarkhan Yarlīqs from the Khanate of Khiva published by W. Wood in 2005, Documents from the Khanate of Khiva, 17-19th Centuries published by Yuri Bregel in 1966, and Jannatkhon Asqarova's master's thesis entitled as A Review on Language and Style of the Correspondences of Turkistan Khanates. Before proceeding to occupation names in the aforementioned works, technical terms in the diplomacy of Turkistan khanates such as yarliq, tarhanlik yarliq, soyurgal yarliq, hukm-i 'alî, emr-i 'âlî and bitik, were
\end{abstract}

*Dr. Öğr. Üyesi, Kafkas Üniversitesi, Fen Edebiyat Fakültesi, Türk Dili ve Edebiyatı Bölümü, e-posta: ncykarahan@hotmail.com

Orcid: 0000-0002-5200-1924 
emphasized and then occupations and titles in these documents were subjected to a classification according to fields of occupation. Every occupation and title name subjected to the classification was also examined in terms of structure and origin and it was aimed to perform a whole assessment regarding relevant name. Structure examinations were primarily based on the data in certain Turkish etymological dictionaries. Present specific studies on occupation and title names were also mentioned. No attribution was made to any reference in studies whose morphological structure was explicit enough not to leave any doubt. The arrangement of occupation and title names was performed in alphabetical order. At the end of the study, it was endeavored to seek an answer to the questions; Which occupation and title names were used in the Turkistan khanates? What kind of needs did they meet? What were the effects and role of occupations and titles on people of the Turkistan khanates? Which language rules were pursued in the establishment of the khanates?

Keywords: Turkistan Khanates, Yarliq, Bitik, Occupations, Titles.

\section{Giriş}

Milletlerin tarihi, kültürü ve etkileşimde bulunduğu toplumlarla ilgili bilgi sahibi olmada önemli bir kaynak olan meslekler, milletlerin medeniyet seviyelerine bağlı olarak çeşitlenmektedir. Karahanl, Uygur, Selçuklu, Çağatay ve Timürlü gibi büyük devletlerin mirası üzerinde kurulan Türkistan hanlıkları; Arap, Çin, Fars, Hint, İran, Moğol ve Ruskültürleriyle yoğun bir etkileşim içerisinde bulunmaları münasebetiyle meslek adları açısından zengin bir literatüre sahiptirler. Bu zengin literatürün derli toplu zikredildiği kaynaklardan birisi de hanlığın başındakilerin ellerinden çıkan iç ve dış yazışma belgeleri olan yarlık ve bitiklerdir.

Yarlıklar, içerik yönünden hanın buyruk, emir ve isteklerini ihtiva eden yazışma türüdür. Türkistan hanlıkları sahasında yarlıkların soyurgal yarlık, tarhanlık yarlığı olmak üzere birkaç türüne tesadüf edilmiştir (Asqarova 2015: 31). Hanın dilediği kişi veya zümreye verdiği ve verildiği kimse ile zümreye çeşitli vergi ve devlet hizmetlerinden muafiyet sağlayıp maddî geniş imkân ve imtiyazlar sunan yarlıklara tarhanlık yarlıkları adı verilir (Özyetgin 2005: 20). Türkistan hanlıkları sahasında tarhanlık yarlıklarının genellikle seyyit, hâce, hacı, kadı, molla, mütevelli, sûfî, şeyh gibi din adamlarına verildiği görülmektedir. Soyurgal yarlıklar ise hükümdar tarafından yararlılık gösteren din ve devlet adamlarıyla askerî personel ve sanatkârlara başarı ve liyakâtlarının mükâfatı olarak tahsis edilen toprakların kullanım imtiyazı için verilen ve aynı zamanda sahiplerine vergi ve devlet hizmetlerinden muafiyet olanağı tanıyan yarlıklardır. Türkistan hanlıklarında ise askerî hizmetler için arazi tahsis etmekve görev tahsisi için yazılmış belgelerdir (Asqarova 2015: 32). "Emir, hüküm, karar, komuta, kuvvet" anlamındaki Arapça hükm kelimesi ile "yüce, ulu" anlamına gelen, Arapça ' $\bar{a} l \bar{i}$ sıfatının bir araya gelmesinden teșekkül eden hü̈km-i ' $\bar{a} l \bar{l}$ divana gönderilen veya buraya gelerek şikâyette bulunanların yazılarına binaen hükümdarın verdiği emirlerdir. Çeşitli konularda bilgi alışverişinde bulunmak için hükümdarların birbirlerine gönderdikleri, emir mahiyeti taşımayan diplomatik mektuplara bitik ${ }^{1}$ adı verilir. Türkistan hanlıklarına ait, haklarında yukarıda kısa bilgilerin verildiği diplomatik yazışmalarda, özellikle de tarhanlık yarlıklarının muhatap olacağı protokol üyelerinin yer aldığı bölümlerin askerî ve idarî meslek grupları ve unvanlar hakkında zengin bilgiler verdiği görülmektedir. Bu belgelerdeki meslekler ve unvanlar incelendiğinde hanlığın askerî, idarî, malî, nakliyye ve ruhanî işlerine bakan memurların meslekleri oldukları görülmektedir. Türkistan hanlıklarına ait belgelerdetespit edilen meslek ve unvan adları şunlardır.

\footnotetext{
${ }^{1}$ Kelimenin etimolojisi ile ilgili olarak bk. (Clauson, 1972: 299b; TMEN-I 717, Özyetgin, 1996: 74-75; Vásáry,
} 1987: 23-27). 


\section{Meslek ve Unvan Adları}

\subsection{Hukuk ile İlgili Meslek ve Unvan Adları}

kāạīi: Arapça ḳazā kökünden ism-i fâil olan ḳậ̣̂̄ kelimesi insanlar arasında meydana gelen ihtilaf, anlaşmazlık ve davaları şer'î hükümlere göre çözüme kavuşturması için yetkili makam tarafından atanan görevliyi ifade etmektedir (Yüksel 2009: 171). Kelimenin Türkistan hanlıklarındaki terminolojik anlamı han veya hanınemri ile bölge hâkimi tarafından kayd-ı hayat şartı ile tayin edilen ve şer'î husumetleri karara bağlayan yargıç şeklinde tarif etmek yerinde olacaktır. Kadılar; nikâh ve veraset konularındaki hassasiyeti gözeterek doğan çocukların kaydını tutma, yetim ve mecnunların mallarının muhafazası ile vâsiliği yürütme, evlilik ve nikâh işlemlerindeki dinî ritüelleri takip etme, muhtesipler tarafından kendisine intikâl ettirilen meselelere çözüm üretme, bölge idarecilerine vaaz ve nasihatlerde bulunma gibi görevleri ifâ etmekteydiler.

bes bu mukaddima [hūurşìd-kadr] [ve] āsmān-bedr karnntaşlar-ga ve hükūmet-penāh sitāre-sipāh berhūrdār og̀lanlar-ga ve 'ālī-makām ve sa'ādet-fercām diyānet ve şecā'at[-l1kșā'ib-rāy] karaçu biylerge muşkīn-rakam ve zerrīn-kalem mülk-ārāy ve șāhib-rāy ferāset-l1kdịvānlarga siyāset ve heybet-lık arslan-layın [aḳnp]yolbarslayın çakıırgan āstān-1 felek-iştibāhda turğan hāāibler-ġa ve

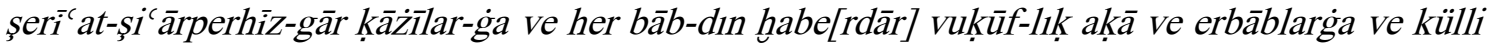

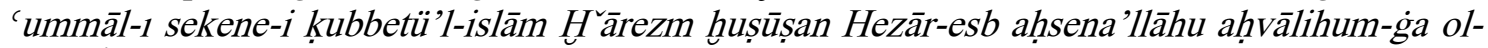
kim 'İslâm'ın kubbesi olan Harezm vilayetinin güneş rütbeli, gökyüzündeki ay (gibi yüce makamlı) kardeşlerine, egemenliğin sığınağı, yıldızlar kadar kalabalık ordusu olan, mutlu şehzadelerine, yüce makamlı, saâdetli, din ve yiğitlik(te) isabetli görüşü olan karaçu beylerine, misk kokulu yazı ile altın kalemi ile memleketi süsleyen, isabetli fikir, ferasetli divanlarına, siyaset ve heybetli arslan gibi kükreyip kaplan gibi bağıran, gökyüzünü andıraneşikte duran hâciplerine, şerî‘atı şiâr edinen, dindâr kadılarına, her bakımdan haberdar ağa ve erbaplarına, bütün iskân eden âmillerine özellikle Hezaresb'e -Allah, onların durumunu iyileştirsin!- o ki”'(HY-T4/5).

müftī:Hanlıklardaki şer'î mahkemelerin esas organlarından biri de müftü idi. Müftü, idârecilerin resen tayin edilmesi, mirzalık görevindenmüftülük görevine terfi ettirilmesi yolu ile bu göreve gelebiliyordu. Mahkemede birkaç müftü yer alabiliyordu ve bunların en yaşlısı bazen "baş müftü", diğerleri ise "molla" olarak isimlendiriliyordu. Bazen da şehrin en büyük mahkemesinde çalışan müftüye "baş müftü" ismi veriliyordu. Bazı mahkemelerde a lam veya mırzanın olmaması nedeni ile müftüler kâdının hem a lam hem mırzası olarak da görev yapıyorlardı. Resmî müftü, mahkemeye gelen davalar konusunda yazılan furû-ı fikıh kitaplarındaki fetvâ, rivayet ve kavilleri derleyip a"lama iletmek ile görevli idi. Ayrıca, müftülerin furû-1 fıkıh türü eserlerinin yanında diğer müracaat ettiği kitap türleri "fetvâ türü eserler", "cung (mezhep içi sahih ve asah görüşleri içeren) eserler" ve "vesâik" şeklinde isimlendirilmiştir (Karıev 2016: 142).

merāhimim-i șāhāne ve 'ātıfet-i hüsrevāne-mizdin ser-bülend ve ercümend k1lip ol șāḥib-i fäzl $u$

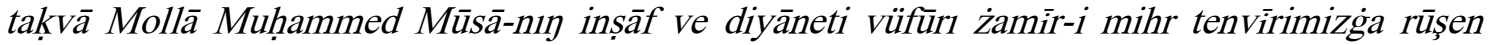
bolg̀anı üçün Hezār-esb Kal'ası-ġa ma'a't-tevābi' ve'l-levāhik Mollā Muḥammed Nazar Ahūnd orniga Mollā Ya' kūb H’āceǵa șerik-i re is ve Molla Seyyid Nazarg̉a şerik-i müftī kıllp nişān-1 'ālişāan soyurgal ḳılduk "şahâne bağışlarla hüsrevâne iyiliklerimizden onurlanıp ve saygınlaşıp o takvâ ve fazilet sahibi Molla Musa'nın (ne kadar) insaf ve diyanetli olduğu, (hanlığımızın) gönül güneşinin nuruna aydınlık olduğu içinHezaresb Kalesi'ne tâbi yer ve tebası ile beraber, Molla Muhammed Nazar Ahund'un yerine Molla Yakup Hace'ye reis yardımcısı ve Molla Seyit Nazar'a müftü yardımcısı atayıp şanı büyük (hanlık) nişanı ile soyurgal kıldık” (Bregel 2007: 21/6).

\footnotetext{
2 Çalışmada meslek ve unvan adı olan terimlerin önce Türkistan hanlıkları belgelerinde geçtiği asıl yerler, Doğu Türkçesindeki şekliyle yazılmış, hemen arkasından ise bugünkü Türkiye Türkçesine aktarımları yapılmıştır. Bu esnada herhangi bir karışıklığa mahal olabileceğinden Türkiye Türkçesine yapılan aktarmalar tırnak içine alınmıștır.
} 
taḥkikķ̧i: Bir şeyin doğru olup olmadığını araştırma, meydana çıkarma anlamlarındaki, Arapça tef'îl veznindeki tahkik (Devellioğlu 1990: 1219) kelimesine isimlerden meslek adları türetmeye yarayan, Türkçe $+c ̧ i$ ekinin getirilmesiyle türetilmiş bir kelimedir. Modern Türk yazı dillerinden Azerbaycan Türkçesinde tehqiq étme, araşdırma, yoxlama işine tehqiqat, heqiqatı ortaya çıxarmaq üçün yapılan tehqiq étme, araşdırma ve yoxlama işlerine tehqiqat aparmak; tehqiqat işlerini aparan resmi şehse ise tehqiqatç (ADİL-IV: 291) adı verilmektedir. Türkistan hanlıklarında tahkkikçilerin çarşı ve pazarların kontrolü, esnafın ticaret ahlâkına uyup uymadığının teftişi, hanlık arazilerindeki cinayet, eşkıyalık, hırsızlık, karaborsacılık, yolsuzluk gibi konuların aydınlatılması işleriyle ilgilendikleri tahmin edilmektedir.

hazīneçi ve tahkikik-çi ve tunkatar ve barsbān tigmesünler "Hazîneci, tahkîkçi, tunkatar ve parsçı dokunmasinlar" (HY-T2/19).

\subsection{Askerlik ile İlgili Meslek ve Unvan Adları}

karaçu biy: "karaçi, karaçu" unvanı Altınordu Devleti'nin ardılları olan hanlıklarda asil beyler için kullanılmıştır. Karaçi kelimesi, Kırım Hanlığında asker başı, asker tayfası ile hanlığın üst kademesinde bir memur unvanıolarak kullanılmıştır ${ }^{3}$. Karaçi biy ise Kırım Hanlığına ait belgelerde Kırım Hanlığında hanlığın önde gelen dört (daha sonra beş) ailesinin -Argın, Barın, Mansur, Şirin ve daha sonraları bunlara dâhil olan Sicuvut- başındaki liderlerini ifade etmek için kullanılan bir unvandır (Atasoy 2017: 557). Kazan Hanlığında Kırım karaçileriyle benzer statüde olup hukukî olarak önde gelen saray uyruklarının beylerine bu unvanla hitap edilmiştir. Söz konusu bu unvan, Nogaylarda oldukça önemli bir makam olup "hizmetli, kul" anlamındaki karaçilerden ayırt etmek için ayrıca "uluğ karaçi" unvanlı kimseler mevcuttu. Yine Kasım Hanlığında "solda karaçu azamet bikleri olturup ..." ifadelerinden bu makamda bulunan kimselerin büyük bir itibar ve saygınlığa sahip oldukları anlaşılmaktadır (SHK I: 55-56). Hive Hanlığına ait tarhanlık yarlıkları üzerine çalışma yapan Wood, çalışmasındaki H. 1111/M. 1700 tarihli Document A olarak kodladığı belgede bulunan bu terim için Abu'l-Gazi Bahadır Han'da "sadık ve sadık hizmetkârlar" anlamına geldiği ve Yadigâr Han'a teslim olan bazı kabilelere referansta bulunduğu bilgisini aktarmaktadır (2005: 35-36). Altınordu, Kasım, Kazan ve Kırım hanlıklarında olduğu gibi, Türkistan hanlarına ait belgelerde de bu unvana sahip beylerin, hanlığın idaresinde önemli yöneticiler olduğu anlaşılmaktadır.

āsmān [her ḳarıntaşlarğa] ve hükūmet-penāh ve sitāre-sipāh berhūrdār og̉lanlarg̉a ve 'ālīmakāàm ve sa'āadet-fercām diyānet ve şecā'at[11k ...] karaçu biy-lerge müşkinn rakam ve zerrīn kalem mülk-ārāy ve șāhib-rāy ferāset-lık dịvān-larğa siyāset ve heybet-lık arslan-layın [aknip]

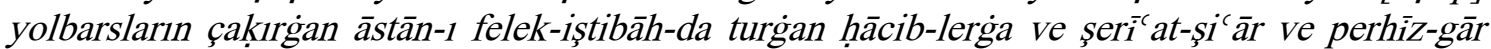
kậ̣īlarga her bābdın haber vukūflık akā ve erbāblarğa ve küll-i 'ummāl-1 sekene-i kubbetü'l-

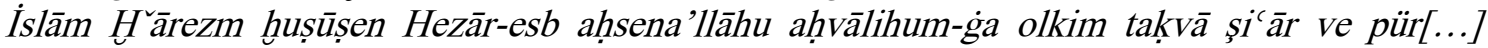
hidāyet-penāh Nedr Muḥammed Şeyhukaddesa'llāhu ta'ālā rūḥuhu'l-'azīz-nin og̉lanları ötken pādşāh-larnın nişānın mübārek nazarımızga kiltürüp imżā iltimās ḳıldılar ‘İslâm'ın kubbesi olan Harezm vilayetinin sema(sı olan)her kardeşe, egemenliğin sığınağı, yıldızlar kadar kalabalık ordusu olan, mutlu şehzadelere, yüce makamlı, saâdetli, din ve yiğitlik ... karaçı beylere, misk kokulu yazı ve altın kalemi ile memleketi süsleyen, isabetli fikir, ferasetli divanlara, siyaset ve heybetli arslan gibi kükreyip kaplan gibi bağıran, gökyüzünü andıraneşikte duran hâciplerine, şerî‘atı şiâr edinen, dindâr kadılara, her bakımdan haberdar ağa ve erbaplarına, bütün iskân eden âmillerine özellikle Hezaresb'e -Allah, onların durumunu iyileştirsin!- o ki takvâ sahibi, ... hidayet sığınağı Nedr Muhammed Şeyh'in -Yüce Allah, onun ruhunu aziz kılsın!-oğulları mazideki padişahların (kendilerine verdiği) mübarek nişanını nazarımıza getirip imza istediler"(Wood 2005: A/4).

\footnotetext{
${ }^{3}$ Detaylı bilgi için bk. (qarāčū, Nichtadliger, Mann aus dem einfachen Volk; Nichtčingiside; Untertan' qarāçūy $\leftarrow$ wmmo. qarāču id. TMEN-I 274).
} 
kuş bigi: Her ikisi de Türkçe olan ḳuş ve big kelimelerinin birleşmesinde meydana gelen kus bigi, Türkistan' da vezir makamında büyük bir rütbe, başvekil, sadrazam (Ata 2008: 178) anlamlarına gelir. Büyük emirlerden biri olan kuş bigi, hanın yakın akrabaları arasından seçilmekte ve savaş bakanı olarak hanla birlikte savaşlara katılmaktayd. Bregel bu terimi anlamlandırırken birbirinden farklı iki terimin birbirine karışmış olma olasılı̆̆ üzerinde durur. Barthold'a göre "hanlık karargâhının (koş) kumandanı"; A. A. Semenov'a göre "sarayın avcı başı" (asıl olarakkuş kelimesinden yola çıkarak saray şahincilerinin başı) (Şişman 2012: 59). Bu unvan, Hive Hanlığ 1 hanlarından Ebû'l-Gazi Allahkulı Muhammed Bahâdur Han'ın Buldumsazmevzisinde mülk-i hăliṣ olarak nitelendirilen iki bin tanablık araziyi askerî hizmet için o zamanın iki bin altın parasına sattığı kişinin unvanı olarak kullanıldığı görülür.

'ināyet-i pādşāhānemizdin ser-efrāz kılıp Nayman Ayaḳı atllg mevżi'-dagì memleket-i pādşāhìga muta'allık yerdin tahminen on min țanāb yerni nöker mevācibi üçün emine'd-devletü'l-

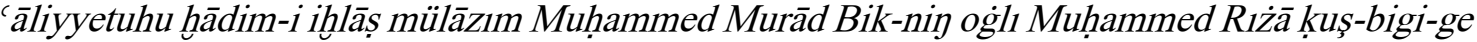
on min tıllă-yı rāyücü'l-vaktğa sattuk" padişahâne inâyetimizle onurlandırıp Nayman Ayakı atlı mevzideki padişahın memleketine ait yerden on bin tanâb(l1k) yeri askermaaşı için yüce devletin güveniliri, ihlaslı hâdimi Mülazım Muhammed Murad Bey'in oğlu Muhammed Rıza Kuş beyi’ne dönemin râyic on bin altınına (tekâbul eden bir meblağ karşılığında) sattık" (HY-T19/4).

kütvel: Kökeninin Hintçe, anlamının ise 'kale komutanı' olduğu belirtilen kelime, dizdâr ve kaledâra karşılık gelmektedir (Göksu 2010: 268). Ataması hükümdar tarafından ihlâs, liyakat ve sadakat sahibi adamlar arasından yapılan, atandığı yerde bulunan kalenin hem valilik, hem de komutanlık ve kale muhafizlığ görevini yürüten kimse anlamındaki kütvelin, Türkistan hanlıklarına ait yarlıklarda genellikle daruga, dervāze-bān ve karavul meslekleriyle ve bâc ve tamġa vergi adlarıyla birlikte kullanıldığı görülmektedir.

[her taraf-ge ticāret üçün] barsalar ve kilseler biy ve karavul ve çihil-yekçi ve dervāze-bān ve kütvel bāc ve tamġa tip bir habbe ve bir dīnār almasunlar "her (ne) tarafa ticaret için gitseler ve gelseler biy, karavul, kırkta bir vergi tahsildârı, kale kapısı muhafızı ve kütvel; bâc ve tamga (vergisi) diye bir habbe (mal) ve bir dinar (para) almasılar" (HY-T7/12).

mīr-i tümen: 'Emir, bey' anlamına gelen, Farsça mîr ileTürkçe büyük vilayetlere bağlı küçük vilayetleri gösteren idarî bir teknik terim olan tümen kelimesinin birleşmesiyle teşekkül etmiş bir kelimedir. Tümen için kaynaklarda 'on bin asker veya on bin dinar vergi veren bölge' açıklamasının yanı sıra Baburnâme'de Semerkand ve Buhara bölgesindeki idarî teşkilatta, büyük vilayetlere bağlı küçük vilayetleri belirten bir terim (Bâbür 2006: 190) olduğu bilgisi mevcuttur ${ }^{4}$. Türkistan hanlıklarına ait yarlıklarda kelime, askerî ve idarî bir meslek grubu olarak karşımıza çıkmaktadır.

dìvān ve terāzūbān ve dīvān bigi ve mìr-i tümen ve mīr-āb ve müsrif ve dervāzebān ve şığavul ve kütvel ve ḳoruġmāl barça 'ummāl ve duhhhāl dah̆l ḳılmasun-lar "divan, tartı memuru, divan beyi, tümen emiri, su emiri, kale kapısı muhafızı, saray teşrifatçısı, kütvel, korukçu, tüm âmil ile dâhil müdahale etmesin" (HY-T2/19).

nöker: Cengizli ve ahfadı olan devletlerde maiyet muhafızlarıla han ve kabile reislerine hizmet eden ve onları efendi tanıyan bağımsız Moğol muhafız silahşörlerini ifade eden bir terimdir. Sözlükte "hizmetkâr, yardımcı, kul, arkadaş" anlamlarına gelen Moğolca nöker kelimesi, Farsça,

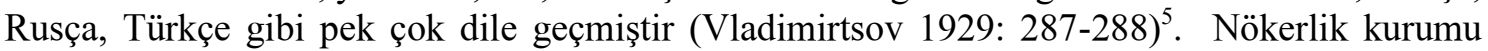
Altınordu, Anadolu Selçukluları, Anadolu Beylikleri, Çağataylılar, İlhanlılar, Celayirliler, Çobanlılar, Timürlüler, Akkoyunlular, Karakoyunlular, Bâburlular, Hîve Hanlığıyla Osmanlılar'da da bazı farklı uygulamalarla varlığını sürdürmüştür.

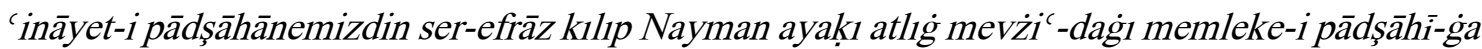
muta'allık yerdin tahminnen on min tanāb yerni nöker mevācibi üçün emine'd-devletü'l-

\footnotetext{
${ }^{4}$ Detaylı bilgi için bk. (TMEN-II 983 tūmān).

${ }^{5}$ Detaylı bilgi için bk. (TMEN-I 388).
} 
'āliyyetuhu hădim-i ihlās mülāzım Muhammed Murād Bik-nin og̉ı Muḥammed Riżā Kuş-bigige on min țllā-yı rāyücü'l-vaktğa sattuk' padişahâne inâyetimizle onurlandırıp Nayman Ayakı atlı mevzideki padişahın memleketine ait yerden on bin tanâb(llk) yeri asker maaşı için yüce devletin güveniliri, ihlaslı hâdimi, Mülazım Muhammed Murad Bey'in oğlu Muhammed Rıza Kuş beyi'ne dönemin râyic on bin altınına (tekâbul eden bir meblağ karşılığında) sattık"(HYT19/4).

serdār: Asker başı, kumandan anlamlarına gelen serdār, Farsça ser 'baş've dārān 'savaşlar' kelimelerinden teşekkül etmiş birleşik bir isimdir (Devellioğlu 1990: 1127). Kelimenin çokluk eki ile beraber kullanılması, hanlık ordusunu meydana getiren her birliğin başındakilerin bu unvanla anılıyor olmasını akla getirmektedir.

her künde ețrāf u cevānib-nin ḥākim ve serdārlarıdın ebed müddet devlet-nin şā̄nnġa münāsib hayr ve tartığlar yetüşür "her gün etraf ve çevrenin hâkim ve serdarlarından ebediyete kadar payidar (olan) devletin şanına münasip yararlı iş ve hediyeler ulaşır" (Bregel 2007: 26/9).

yüz başı/bigi: Türk-Moğol devletlerinde yüz kişilik askerî birliklerin başlarında bulunan görevliler. Türkistan hanlıklarına ait belgelerden hareketle hanlıktaki birliklerin diğer Türk devletlerinde olduğu gibi, yüz beyi, bin beyi ve tümen beyi olarak sinıflandırıldıkları

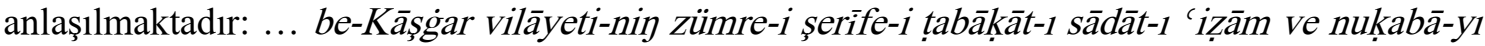
kirām ve nücebāa-yı evlād-1 hażret-i seyyidü'l-enām 'aleyhi'ṣ-șalāvatu ve's-selām ve 'ulemā-y1 huceste kelām ve fużelā-yı takvā fercām ve kużät-1 şerī'at encām ve șudūr-1 'ālī-makām ve hükkām-1 zevī'l-iḥtișām ve rü' 'esā-yı nikkū-nām ve cumhūr-1 havāṣ(ș ü) 'avāmı bile tümen bigi min bigi yüz bigi aymak bigi hūrçīn bigi işçi küssçi mütevelli tavaçı tüşimel küll(i) 'ameldār șāhib cem' bitikçi-leri..."Kaşgar vilayetinin şerefli tabakasının zümreleri olan ulu seyitleri, temiz soylu nâkibleri, Allah'ın salat ve selamının üzerine olduğu, bütün halkın efendisi (Hz. Muhammed'in) necip evlatları, kelâmı hayırlı âlimleri Allah'tan korkmaları (hususunda ikaz eden) erdem sahipleri, şeriâtın yıldızları olan kadıları, makamı yüce olan başkanları, ihtişam sahibi hâkimleri, nâm sahibi reisleri, ileri gelenler ve halk kalabalığı ile tümen beyi, bin beyi, yüz beyi, oymak beyi, muhafız beyi, iş küç (yükümlülüğü) memurları, vakıf yöneticisi, tavacı, tüşümel, bütün memurlar, sâhib-i cem kâtipleri ile" (Raquette 1930: 15).

Yine Kara Yusuf'un, bazı mahallerin gelirlerini Emîr Şemseddîn'e ihsan ettiği Rebîülevvel 820/M. Nisan Mayıs 1417 tarihli, Farsça soyurgal fermanda șadecāt unvanına tekabül eden askerî bir terim olduğu anlaşılmaktadır: ümerā-yı ulusāt ve tümenāt ve hezārecāt ve șadecātve serdārān ve hü̈kkām ve 'ummāl ve erbāb u kelānterān ve ahālì ve a'yān ve kedhüdāyān ve melikān-1 Kürdistān 'umūmen ve ușūl ve ma'ārif ve meşāhir ve mütevatțnān ve sākinān-1 Bidlīs ve Ahlāt ve Mūş ve Hunūs ma'a tevābi' ve levāhị be-dānend ki 'Kürdistan'ın ulus, tümen, bin ve yüz emirleri, serdarları, hâkimleri, âmilleri, erbâbları, kelanteri, ahalisi, ayanları ile genel olarak Bitlis, Ahlat, Muş ve Hınıs'la buralara bağlı yerlerin asilleri, maârifi, meşâhiri, mütevattın ve sakinleri bilsinler ki ...” (Kök 2020: 464-466). Türkistan hanlıklarında yüz asker çıkaran yerlerin idarecileri için kullanıldığı tahmin edilmektedir. İran sahası Türk devletlerinden Safavîlerde özel adın sonuna geldiği görülürken Türkistan hanlıkları belgelerinde bu unvanın özel adın önüne geldiği tespit edilmiştir.

bu eyyām-ı ferāh-intizām ve 'umdetü'l-evliyā ve zübdetü'l-etkıyāsı-nı̄ āstāne-i fayż nişānlan1nın şuyūh ve cārūb-keş-leri cümle-si-din Nür Muhammed Şeyh-nin 'anber ferzend-leri-din biri Yüz başı İs Muhammed Şeyh ve 'A vaż Muhammed Şeyh ve Bay Muhammed Şeyh ve KutlukMurād Şeyh dergāh-1 'ālem-penāhımız-ga kilip du' $\bar{a}$ ve alkış-dın sonra kadìmu'l-eyyām-dın bu

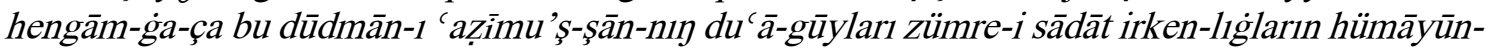
1 sem'imizga yitkürdiler "sevinç intizamlı bu günler(de) velîlerin dayanağı, takvâ sahiplerinin seçkininin feyizli eşiğinin şeyh ve süpürgecileri cümlesinden Nur Muhammed Şeyh'in oğullarından biri Yüzbaşı İş Muhammed Şeyh ve Avaz Muhammed Şeyh, Kutluk Murad Şeyh; âlemin sığınağı olan dergâhımıza gelip dua ve iyi dilekten sonra geçmişten bu zamana kadar bu 
şanı büyük hanedanın duâcıları (ve) seyyitler zümresi(ne mensup) olduklarını padişahlık kulağımıza ilettiler" (HY-T70/5).

\section{3. İç Güvenlik ile İlgili Meslek ve Unvan Adları}

daruga: Vali, askerî vali, bir bölgenin idare ve inzibatıyla görevli memur, muhafız; idare amiri, şehir komutan1. ${ }^{6}$ Şahne ve basķak ile eş anlamlı olan daruga kelimesinin kök şekli olan daru-, tıpkıbas- gibi "bask1 yapmak, zorlamak" anlamlarına gelmektedir (Schurmann 1956: 343). ${ }^{7}$ Doğu Türkistan'da dofga, Azerbaycan Türkçesinde darga şekillerini alan (Köprülü 1983: 248), XIII. yüzyıldan XVIII. yüzyıla kadar Çin'den Kırım'a uzanan geniş bir coğrafya içinde mevcut olan, eski Uygurlara ait sivil belgelerinde taruga şeklinde tanıklanan kelime (Özyetgin 2004: 160-161) ile ilgili olarak İran sahası Türk devletlerinden Akkoyunlu ve Safavîler döneminde darugaaların hizmetlerine karşı1ık darugag $\bar{i}$ veya rüsūm-1 darugag $\bar{i}$ adı verilen bir vergi aldıkları bilgisi mevcuttur (Kök 2020: 1732).

Tarihî belgelerle edebî eserlerden büyük şehirlere, küçük kasabalara, köylere hatta belirli bir meslek gruplarının üzerlerine darugalar tayin edildiği tanıklanabilmektedir. Merkezî idarede önemli vazifelerin başındakilere tahsisatlarını arttırmak maksadı ile herhangi bir şehrin darugalığının tevcih edilebildiği Safavîlerde darugaalar, şehrin asayiş, inzibat ve zabıta işleriyle ilgilendikleri ve kazaî salâhiyetlere mâlik oldukları görülmektedir (Köprülü 1983: 251-252). Türkistan hanlarına ait tarhanlık yarlıklarının inscriptio (kitabe, yazı) bölümünde yarlığın muhatap olacağı kişilerin ve meslek gruplarının adları sayılırken geçen meslek adlarından biri olmasının yanı sira karavul, toḳsavul, bācbān, keştī-bān, dervāzebān, terāzubān gibi vergi toplayıc1ları ile birlikte anılması verginin toplanması ve hanın sarayına gönderilmesi vazifeleriyle de ilgilendikleri anlaşılmaktadır.

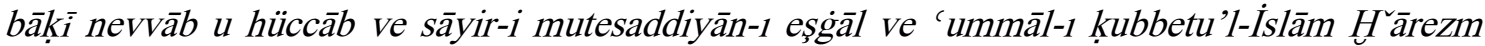
hususụsan dāru's-salțana-i Hìvak bile Hezār-esb beldesi-nin sādāt-1 'izām kuzużāt u fużalā aḥālì ve mevāli vażī' ü şerīf kavī vü ża'îf ve her bābdın vukūflık ulug erbāb darugia ve kelāntān aḥsena'llāhu aḥvālihum-ġa ol-kim... 'İslâm'ın kubbesi olan Harezm' in bâkî nâipleri ve hâcipleri ile vesayir meslek girişimcileri, âmilleri özellikle saltanat yurdu Hive ile Hezaresb beldesinin ulu seyyitleri, kadıları, fazılları, ahali, efendileri sıradan veya soylu, güçlü ya da zayıf her hususta vakıf büyük erbap, daruga ve kelanterine -Allah, onların durmunu güzel kılsın!- o ki ..." (HYT21/8), heme belā ve bid'atdin beri bilip sūdā üçün her țarafğa barsalar ve kilseler karavul ve toḳsavul bācbān ve kime darugiaları ve keştī-bān ve dervāzebān ve terāzubān bir habbe ve dīnār tama' ve tavakku'kılmasunlar 'bütün bela ve bid'attan uzak bilip ticaret için her nereye gitseler ve gelseler karavul, yol muhafızı, bâcdâr, gemi darugaları, gemiciler, kale kapısı muhafizı ve tartı memuru bir habbe (mal) ve(ya) dinar beklemesin ve ümit etmesinler" (Bregel 2007: 10/23).

dervāze-bān:'Kap1, kale kapısı, şehir kapısı' (Devellioğlu1990: 211) anlamlarındaki, Farsça

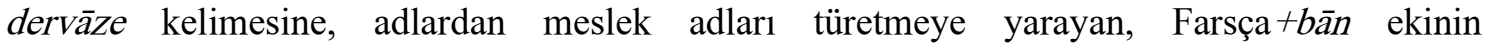
getirilmesinden teşekkül etmiş bir kelime olup kale kapısı, şehir kapısı muhafızı demektir. Dervāzebānlar şehir kapılarını tutarak hem şehrin güvenliğini sağlamakta, hem de şehre gelen mallardan gümrük vergisini tahsil etmekteydiler (Wood 2005: 43). Kale kapısı muhafizı olan dervāzebānların, hem şehir kapılarını tutarak güvenliği sağladıkları, hem de şehre ticaret için gelenlerin mallarından vergiler aldıkları anlaşılmaktadır.

dervāze-bān ve bars-bān ve darugia ve kütvel ve korukmāl alardın bir habbe ve bir dīnār tama'ḳılmasunlar.. "kale kapısı muhafızı, parsçı, daruga, kütvel ve korukçı onlardan bir habbe (mâl) ve bir dinar (para) beklemesinler" (HY-T67/29).

karavul: Genellikle atlı askerden oluşan öncü birlik, keşif kolu, müfreze; bekçi anlamlarına gelen, Moğolca bir kelime (Barutçu Özönder 2011: 43). ${ }^{8}$ Belgelerde biy, çihil-yekçi, dervāze-bān ve

\footnotetext{
${ }^{6}$ Detaylı bilgi için bk. (TMEN-I 193 dārūgaa).

${ }^{7}$ Detaylı bilgi için bk. (Cleaves, 1953: 59-237; Vásáry, 1976: 187-197; Manz, 1985: 59-69).

${ }^{8}$ Detaylı bilgi için bk. (qarāvul 'Spähtrupp, berittene Patrouille' TMEN-I 276).
} 
kütvel gibi hanlık görevlileriyle birlikte karavulunda bezirgân ve tüccarlardan bāc ve tamġa vergisi aldıkları anlaşılmaktadır.

her yerge barsa ve kilse biy ve karavul ve çihil-yekçi ve dervāze-bān ve kütvel bāc ve tamġa tip bir ḥabbe ve bir dīnār almasunlar ilçi ve yolçı iş ve küç üstünde ve külli ḩāșșa mülāzımlar ivlerig̀a tüşüp konalga ve süysün tilep gele karalarındın ulag tutmasunlar "her nereye gitse gelse biy, karavul, çihil yekçi, kale kapısı muhafızı ve kütvel; bâc ve tamga (vergisi) deyip bir habbe (mâl) ve bir dinar (para) almasınlar. Elçi, yolcu, bütün hizmetlilerile hassa mülâzımları evlerine (zorla) misafir olup konalga ve süysün (vergisi) dileyip sürü ve hayvanlarından ulag (hayvanı) tutmasınlar" (HY-T5/12), her yerge sūdāga barsa-lar ve kilse-ler karavul ve çihil-yekçi ve dervāze-bān ve ilçi ve yolçı dāhil ve mużāhim bolmasunlar "her nereye gelseler ve gitseler karavul, çihil yekçi, kale kapısı muhafızı, elçi ve yolcu (onlara) müdahale edip sıkıntı çıkarmasınlar" (HY-T15/15).

koruġbān/ḳoruġmāl: Türkistan hanlıklarına ait tarhanlık yarlıklarında korug̈bān koruġmāl korukmāl şekillerinde tanıklanan kelimenin etimololojisi biraz problemli görünmektedir. Bununla birlikte kelimenin, hana ait, yasak ve koruma altında olan koru, küçük orman anlamındaki korı $\dot{g}$ tan teşekkül etmesi kuvvetle muhtemeldir. Kelimenin türediği korıfiili 'korumak' anlamı çerçevesinde Türkçenin tarihî ve modern yazı dillerinin pek çoğunda görülür (Clauson 1972: 645b-646a). Clauson sözcügü kor1- 'korumak' eylemine dayandırmış, 'kapalı yer, bölge' karşılı̆̆ını verdikten sonra sözcüğün Moğolcada korıga(n) 'kapalı yer, avlu' biçiminde alıntılandığını Haenisch ve Kowalevski'den aktarmıştır (1972: 652b). Erdal da sözcüğün kökünü korı- olarak belirtmiş, sözcüğün bu eylemin nesne adı olduğunu ifade etmiştir (Erdal, 1991: 193-194). Senglâh'ta koruk şeklinde yer alan ve Clauson'un 'koruma, sığınma' olarak anlamlandırdığı (1972: 652b) kelime için diğer Çağatayca sözlüklerde 'koru, konut, sığınak, koruyan' anlamları verilmiştir (DTO: 428; LÇ: 235a). Räsänen *korı şeklinde maddebaş1 olarak verdiği kelimeyi 'koruma, himaye; savunma, müdafaa; barınak, sığınak' anlamlarıyla Doğu Türkçesinden ķoruk şseklinde aktarmıştır (1969: 282b). ${ }^{9}$

Türkistan'da hanın mezarının bulunduğu alan, avlağı veya ona ait mera ve otlaklar koruk olarak nitelendirilebilir. Söz konusu alanlardan han sarayının odun, ot, saman gereksinimleri karşılanırdı. Bu tür alanlara bakan görevlilere ise koruǵbān/ḳoruğmāl adının verilmesi ihtimal dâhilindedir. Ancak kelimenin sonundaki māl; tarihî ve çağdaş Türk dili alanında tek başına hayvan, para ve vergi anlamları ile kullanılırken bu tür bir kullanımı tanıklanmamaktadır. Usmanova; Türkçede āmāl diye bir addan ad türetme eki bulunmadığı için söz konusu kelimenin Türkçe koruk ile mal, sürü, ağaçlık, otlak anlamına gelen, Arapça māl sözlüklerinden teşekkül etmiş birleşik bir kelime olarak izah eder (1964: 107-109). Wood; bağlamdan ve terimin korukbān şeklindeki alternanslı kullanımından hareketle bu kelimenin bir vergi adı değil de, koruk vergisini tahsil eden, resmî bir görevli olma ihtimali üzerinde durur. Yine XIX. yüzyılda Hokand Hanlığı'nda korukçı adı verilen bir görevlinin, hana ait koruktan otlak, odun ve yakacak toplayanlardan bir vergi topladığı bilgisini verir (2005: 41-43). Bununla birlikte, Türkistan hanlıklarına ait tarhanlık yarlıklarında söz konusu memurların tarhanlık belgesi verilen kimselerden en ufak bir şey istememeleri ve beklenti içerisinde olmamaları hususunda uyarıldıkları görülmektedir.

bārsbān ve keşti-bān ve ḳorug̉bān ve dervāzebān bir d[īnār ...] ve bir habbe țama' ḳllmasunlar 'parsçı, gemici, korukçu ve kale kapısı muhafızı bir dinar (para) ve bir habbe (mal) beklentisi içerisinde olmasınlar" (Wood 2005: A/10), ), bārsbān ve keşti-bān ve ḳoruḳmāl ve darvāza-bān bir habbe ve bir dinār tama' ḳılmasunlar ve każu ve ḳaçu bīgār ve haşar buyurmasunlar "parsçı, gemici, korukçu ve kale kapısı muhafızı bir dinar (para) ve bir habbe (mal) beklentisi içerisinde olmasınlar. Kazu, kaçu, bîgâr ve haşar (vergisi) buyurmasınlar" (Wood 2005: D/13), dīvān ve terāzū-bān ve dīvān bigi ve mìr-i tümen ve mīr-āb ve müssrif ve dervāze-bān ve şig̉avul ve kütvel

\footnotetext{
${ }^{9}$ Detaylı bilgi için bk. (TMEN-III 1465 qorug̣çi, "Wächter über etwas, das tabuisiert ist'; Barutçu, Özönder 2011: 38).
} 
korugimāl barça 'ummāl ve duhḩāl dahl ḳlmasun-lar "divan, tartı memuru, divan beyi, tümen emiri, su emiri, kale kapısı muhafızı, saray teşrifatçısı, kütvel, korukçu, tüm âmil ile dâhil müdahale etmesin"(HY-T2/19).

şig̉avul: <Moğ. mihmandar, teşrifatçı (Barutçu Özönder 2011: 43-44), saray teşrifatçısı olarak saray protokolünü takip ve tertip eden görevli (Seng. 260r28; Abuş. 297; LÇ: 205a; DTO: 380). ${ }^{10}$ 'Korumak, mihmandarlık etmek' anlamlarındaki şiğa- fiiline, fiil kök ve gövdelerine gelerek genellikle topluluk adları türeten Moğolca asıllı -GUl'un Doğu Türkçesindeki şekli olan -AvUl ekinin getirilmesiyle teşekkül etmiş bir meslek adıdır (Teres 2009: 329). Türkistan hanlıklarına ait tarhanlık yarlıklarında şig̉avulların tarhanlık belgesi verilen kimselerden en ufak bir şey istememeleri ve beklenti içerisinde olmamaları hususunda uyarıldıkları görülmektedir.

dìvān ve terāzū-bān ve dìvān bigi ve mìr-i tümen ve mīr-āb ve müssrif ve dervāze-bān ve şiğavul ve kütvel korugimāl barça 'ummāl ve duhhhāl dah̆l ḳlmasun-lar "divan (memurları), tartı memuru, divan beyi, tümen emiri, su emiri, kale kapısı muhafızı, saray teşrifatçısı, kütvel, korukçu, tüm âmil ile dâhiller müdahale etmesinler" (HY-T2/19).

tokssavul: Transit olarak geçen tacirlerin güvenli bir biçimde yollarına devam etmelerini sağlayan yol muhafızı, jandarma teşkilatı (Togan 1981: 239). İran sahası Türk devletlerinin yazışmalarında mustah̆fizān-ı şevāri ${ }^{\dagger}$ ve rāhdār olarak geçmektedir. ${ }^{11}$ Tahsisatlarının merkezî idare tarafından temin edilip merkezdeki büyük bir askerî âmirin emri altında bulunan toksavullar, yollar üzerinde türeyip kervanları yağmalayan ve keyiflerine göre vergiler alan eşkıyalara karşı mallarını transit olarak hanlığın topraklarından geçiren yahut hanlık topraklarında kalan tacirlerle bezirgânların mallarıyla canlarının güvenliğini temin ederlerdi.

heme belā ve bid'atdin beri bilip sūdā üçün her țaraf-ga barsalar ve kilseler karavul ve toksavul bāc-bān ve kime darugiaları ve keştī-bān ve dervāze-bān ve terāzū-bān bir habbe ve dīnār țama' ve tavakku 'kılmasunlar gele ve karalarıdın ulag tutup āzūrde-dil ve rencīde könül ḳlmasunlar ve

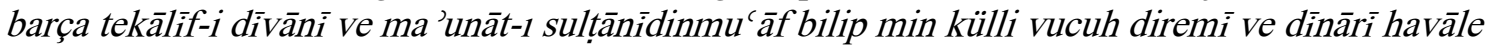
ve muțālibe itmesünler 'bütün bela ve bid'attan uzak bilip ticaret için her nereye gitseler ve gelseler karavul, yol muhafızı, bâcdâr, gemi darugaları, gemiciler, kale kapısı muhafızı ve tartı memuru bir habbe (mal) ve(ya) dinar (para) beklemesin ve ümit etmesinler. Sürü ve hayvanlarından ulag(hayvanı) tutup kalplerini kırıp incitmesinler. Her türlü divan yükümlülükleri ile sultanlık maunlarından muaf bilip hiçbir şekilde (bir tek) dirhem ve dinar (vergi) yüklemesinler ve talepte bulunmasinlar" (HY-T54/23).

tünkatar: Türkçe 'gece' anlamındaki tün adıyla 'eklemek, ilave etmek' anlamındaki kat-fiilinin birleşmesiyle teşekkül etmiş bir meslek adıdır: < T. tünkatar [< ET (Orh) tün "night" (Clauson 1972: 513a) < AT *tün (Tekin 1995, 185)+ET (Orh) kat- "to mix, to add" (Clauson 1972: 594b) -ar. Kelime çağdaş Türk yazı dillerinden Kırgız Türkçesinde tun kat- şekli ve "bütün gece yürümek" anlamıyla tanıklanmaktadır (Arat 1987b: 658). Yine benzer bir kullanım Babürname'de de görülür... atlanıp kečä tün qatıp yarım kečä Xan Yurtıga yettük “... at binip gece boyunca yürüyerek gece yarısında Han Yurdu'na ulaştık." (Thackston 1993: 169/83a). Dolayısıyla tünkatar kelimesi, daha sonraki devirlerde teşkil edilmiş olmalıdır. "Çağatayca:" gardien de nuit autour de la tombe ou de la demeure desrois" (Courteille 1870: 248) || tonḳatar "Nachtwätchter, nächtliche Leibwacheder Fürsten; de nuit, garde nocturne pour le service des princes" (Vámbéry1867: 267a) || tunktar "seferde hükümdarın otağ ve haymesinin muhafizı, gecepasbani, bekçi; amir ata suvar olduğu anda avaz bulend ile dua edici” (Kúnos1902: 196) ॥ tün kutar (Seng. 1960: 187r 7) || tün ḳatar 'gece ile padişahı bekleyenler' (Kaçalin 2011: 1027).Doerfer'e göre bu kelime Farsçaya da [tunqațār, tunqițār, tunquțār "Anight watchman, a taper, rushlight", tunqațārī "The duty of a night watchman, nightly guard" (Steingass 1892: 329a)]

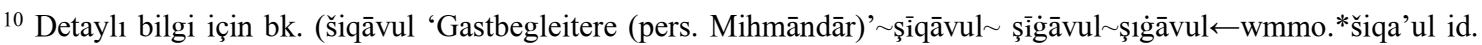
TMEN-I 232).

${ }^{11}$ Detaylı bilgi için bk. (totqāvul TMEN-I 124).
} 
geçmiştir. ${ }^{12}$ Türkistan hanlıklarına ait belgelerde han ve sarayını bekleyen gece muhafizları anlamıyla kullanıldığı düşünülmektedir.

hazinneçi ve tahkkik-çi ve tünkatar ve barsbān tigmesünler 'Hazîneci, tahkîkçi, tunkatar ve parsç1 dokunmasinlar" (Bregel 2007: 3/19).

\subsection{Avcılık ile İlgili Meslek ve Unvan Adları}

bārs-bān:Vahşi hayvan terbiyecisi. ${ }^{13}$ Eskiden beri insanlar avlarda, kendi eğittikleri kaplan, köpek, pars ve peleng gibi hayvanlarıavlanmada kullanagelmişlerdir. Bu ișle ilgilenen ve hanın av işlerini düzenleyenavcı başılar veya parsçılar devlet idaresinde vazifeliydiler. Nitekim av esnasında hükümdarın yanında yer alan parsçıların İlhanlı, Akkoyunlu ve Timürlülerde devlethâne veya devlethâne-i pâdişâhî olarak adlandırılan yönetim merkezinde kullukçı sınıfının içerisinde görev yaptıkları (Erşahin 2002: 295) belirtilmektedir. İncelememizde soyurgal ve tarhanlık belgesinin verilip daha çok vergi ve yükümlülüklerden muafiyet tanınan kişi veya zümrelere müdahalede bulunulmaması için ikaz edilen meslek gruplarındandır.

bārs-bān ve keştī-bān ve koruġ-bān ve dervāze-bān bir [dīnār] ve bir habbe țama Kklmasunlar kazu ve kaçu haş̧ar ve bīgāarr] buyurmasunlar her țarafge sūdāga barsa ve kilseler çihil-yek ve bāc ve tamġa ve rāh-dārlık ve hazinne-ç-lık tip hịç nimerse tama 'kılmasunlar ve hịç vech-din żarar zahmet tigürmesünler... "parsçı, gemici, korukçu, kale kapısı muhafızı bir dinar (para) ve(ya) bir habbe (bir mal) beklemesinler. Kazu, kaçu, haşar ve bîgâr (vergisi ve yükümlülügü) buyurmasınlar. Her nereye ticarete gitse ve gelseler kırkta bir, bâc, tamga, râhdârlık ve hazinecilik (vergisi) diye hiçbir şey beklemesinler. Hiçbir şekilde zarar ve zahmete sokmasınlar"(HY-T4/10).

kuşç1: <ḳuş+çı kuşçu, kuş terbiyecisi (Barutçu Özönder 2011: 38). Ad gövdesinin kökünü meydana getiren kuş kelimesi, Türk dilinin tarihî ve modern lehçelerinin tamamında tanıklanmaktadır (Levitskaya 2000: 180). Türk devlet geleneğinde hükümdarın avcı kuşlarınının ve haberleşmede kullandıkları güvercinlerinin yetiştirilmesiyle görevli kimse, kuş bakıcısı, kuş terbiyecisi olup Farsçadaki bāz-dār,mīr şikār başı-gerī terimine karşılık gelmektedir. ${ }^{14}$ İncelenen belgelerde kuşşı kelimesi ile Türkistan sahasında hanın hizmetinde çalışan, onun adına avlanan ve av hayvanlarına tuzak kuran kimselerin kastedildiği anlaşılmaktadır.

ilçi ve yolçı ve kuşçı ve bar-ğuçı ve kilgüçi ve cerib-i dīvānì ivlerig̉a tüşüp ḳonalg̀a ve süysün tilemesünler gele ve karalarıdın ulag tutmasunlar "elçi, yolcu, kuşçı, giden gelen, divanın cerîb (memuru) evlerine uğrayıp konalga ve süysün (vergisi) dilemesinler. Sürü ve hayvanlarından ulag(hayvan1) tutmasınlar" (HY-T6/10).

\subsection{Bürokrasi ve Yöneticilik ile İlgili Meslek ve Unvan Adları}

aḳa: Aslı Moğolca olup "büyük kardeş, ağabey; bir devlet adamı makamı"15 olarak kullanılan bu kelime Türkçede çok geniş bir yayılma alanı bulmuş bir unvan ve rütbedir. Türkistan hanlarına ait tarhanlık yarlıklarında erbāb kelimesi ile hep bir arada anılan bu unvandan aǵaça, aǵalık, kapu ağası, otaǵası, tör ag̉a, yol ag̉ası (Ata 2008: 178), kurçı ākāāsı, kullar ākāsı ve işik ākāssı (Kök 2020: 1712) gibi türemiş ve birleşik yapılı unvan adlarının teşekkül ettiği, Safavîler zamanında bu unvana sahip kimselerden müteşekkil silk-i ākāāān-1 'izām" “büyük ağalar zümresi” (Kök 2020: 1151) adı altında bir grubun olduğu tespit edilmiştir. Türkistan hanlıklarına ait belgelerde bu kimselerden her bāb-din vukūfllk" her hususta bilgi sahibi" (HY-T2/7) olarak bahsedildiği görülmektedir.

\footnotetext{
12 Detaylı bilgi için bk. (TMEN-II 1965: 940 tünqațār, 'Nachtwächter; eine die ganze Nacht hindurch brennende Kerze' - tünqatār $\leftarrow$ tü. Tün-qatar id).

${ }^{13}$ Detaylı bilgi için bk. (< bars+çı, bars “leopar”, Clauson 1972: 368a; barsçi “Hof-Jadgepardenwart” TMEN-II 686; Barutçu Özönder 2011: 37).

${ }^{14}$ Detaylı bilgi için bk. (qūşçī TMEN-III 1967: 1564).

${ }^{15}$ Detaylı bilgi için bk. (TMEN-I 22 ursprünglich ‘älterer Bruder' āàḡă wmmo. aqa id).
} 


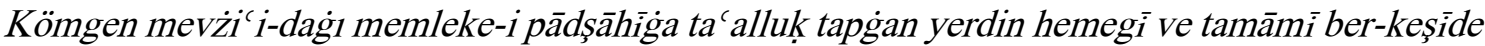
yigirme tanāb yerni barça hukūk ve murāfikı bile mevācib-i nökeriyye üçün Aka Muhammed-nin og̀lı Baba Cān-ġa yüz țllā-yı rāyicü'l-vaktğa sattuk "Kömgen mevzisindeki hanın memleketine ait olan yerden hepsi ve tamamı(nın sınırları) çekilmiş yirmi tanâb yeri tüm hukuk ve murâfıkı ile birlikte nökerlik mevâcibi için Aka Muhammed'in oğlu Baba Can'a zamanın yüz râyic altınına

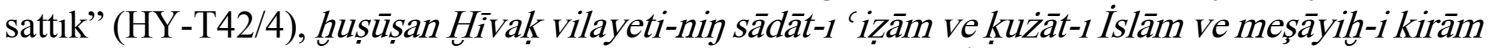
ahāli ve mevāli aḳa ve erbāb ve külli 'amel-dārlarıġa ol-kim 'İyd Şeyhu-nin og̀lı Yār Muhammed Şeyḩve Muhammed Emin Şeyh̆ ve Huseyn Şeyh ve Lațī Şeyh̆ burunkı ötken pādşāhlar nişānların dergāh-1 'ālem-penāhda mübārek nazarım-ga kirgüzüp imżā iltimas ḳıldı irse biz takı körüp ve bilip kadīm destūrnnça nişān-1 soyurğal kılduk 'ôzellikle Hive vilayetinin ulu seyyitleri, İslâm'ın kadıları, kerem sahibi şeyhleri ve mevâlileri, ağa, erbâbı ile tüm ameldârlarına o ki İyd Şeyh'in oğlu Yâr Muhammed Şeyh, Muhammed Emin Şeyh, Hüseyin Şeyh ve Latîf Şeyh mazideki padişah nişanlarını âlemin sığınağı olan dergâhta mübarek nazarıma girdirip imza iltimâs kıldığında biz de (bu nişanları) görüp ve bilip kadîm destura göre soyurgal nişanı verdik" (HY$\mathrm{T} 5 / 7)$.

atalık: <ata-1ık. 'ced, baba' anlamındaki, Türkçe ata kelimesine addan ad türetme eki + lık ' $1 n$ eklenmesinden meydana gelen atalık, Türkistan'da bir rütbe, hanın tuttuğu ve pederi gibi itimat ettiği adam, ahalinin istek ve hakların dinleyip padişaha tebliğ ve arz etmeye ve babalık sıfatıyla müşfikâne hâl ve keyfiyetlerinden agâh ve haberdar olmağa memur (Ata 2008: 177) kimseler için kullanılan bir unvandır. Selçuklulardaki atabeylik ile Osmanlı ve Safavîlerdeki lalalık müessesesine tekâbul eden atalık, bir tarafıyla danışmanlık makamını diğer tarafıyla yasa doğrultusunda han ve sultanların verasete dayalı sahip oldukları bölgelerde sürdürdükleri hükümranlıklarına dair denetleme görevlerini yerine getirmişlerdir. Diğer bir ifadeyle atalık, Türkistan hanları için merkezi otoritenin sağlanması amacına yönelik bir makamdır. Nitekim güçlü hanlar, atalıkları kendileri atamış ve bunların üzerinden sürekli bilgi akışı sağlamıştır. Şehzadelerin, hanlığın başına geçmesiyle de atalıkların sadaret makamına getirildikleri olmuştur.Türkistan hanlıklarında hususî bir anlam ve önem arz eden atalık unvanı, Cengiz sülalesine mensup hanlarda, yani asıl hükümdarlarda değil, bu unvanı taşıyan beyler olan Özbek şehzadelerinden birinin elinde bulunmaktaydı. Cengiz neslinden birinin han ilan edilmesi halinde onun namına hükümdarlık süren Özbek beyleri atalık değil de, ınak unvanını kullanmışlardır (Köprülü 1983: 157-158). Hanların çocuklarını yetiştirip eğitimleri ile ilgilenen ve Rusların "dadka" olarak adlandırdıkları bu görevlinin oturduğu makama atalıklık adı verildiği belgelerden anlaşılmaktadır.

hükkām-1 sabıka-i merhūmi-lerdin tā bu küngeçe te' āmül bu kim Kinik mevi̇'ídag்1 atalık-lık bolg̀an yerni pādșāh-1 İslām-penāh atalık-11kmansıbı-ġa kim-ni münāsib körüp atalık kılsalar ol yerni 'amaläti-nì i'tibārıdın atalık bolgan emāret-penāh-ğa mihribān bolur "merhûm sabık hükümdarlardan ta bu güne kadar teâmül bu(dur) ki Kinik mevzisindeki atalıklık olan yeri İslâmın sığınağı olan padişah atalıklık makamına kimi münasip görüp atalık (tayin) kılsalar o yeri tayininden itibaren atalık olan (o) emirlik sığınağına ihsan olunur” (Bregel 2007: 30/4).

bik: Türkçenin yazılı ilk belgelerinden günümüze kadar gelen bu unvan, Türkistan sahası belgelerinde 'asilzâde' anlamını ifade etmektedir. Hükümdar, şehzade, lala, beylerbeyi, vassal devletlerin yöneticileri, elçi, hâkim, üst düzey ordu mensupları görevindeki kimselerin adlarından hemen sonra gelerek san belirttiği gibi, bigüm biçimiyle hükümdar sülalesine mensup bayanlar için kadın adlarıyla veya İran sahasında ata big, bigler bigi, çōbān bigi, dīvān bigi, kal'a bigi, kur bigi gibi kelimelerle birleşerek yüksek mevki ve vergi adları teşkil etmeye yarayan Türkçe bir kelimedir (Kök 2020: 1723). Beg. ${ }^{16}$ Söz konusu unvanın, Türkistan sahasında çok saygın -divan üyesi olması münasebetiyle- ve yaygın bir idarî ve mülkî tabir olduğu esātịnn-i bārgāh-1 hüsrevāni "padişahlık divanının ileri gelenleri” (HY-T2/6) olduğu görülmektedir.

${ }^{16}$ Detaylı bilgi için bk. (bék TMEN-II 1963: 828). 


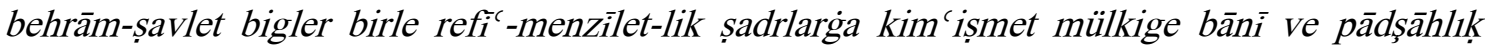
şevketi-nin nigeh-bānı irürler 'Merih savletli beylerle yüce menzilli sadrlara ki (onlar) ismet mülkine mimar ve padişahlık şevketinin gözcüsüdürler”(HY-T6/4).

biy: Oğuz lehçesinde beg bey, Doğu Türkçesinde big şeklinde olan, eski Türk unvanının Kıpçak lehçesinde aldığı şekil (Köprülü 1983: 231). ${ }^{17}$ Başkurt, Karakalpak, Kazak, Kırım, Kırgız ve Özbek Türkleri arasında kabile reisinin ortak adıdır. Munis bu unvanın noyan unvanı yerine kullanılmaya başlandığından bahsetmektedir. Biy rütbesi ınak ve atalık rütbesinden daha aşağ bir rütbe olup Abu'l-Gazi'nin han meclisi üyelerindendir (Şişman 2012: 62). İncelememizde soyurgal ve tarhanlık belgesinin verilip daha çok vergi ve yükümlülüklerden muafiyet tanınan kişi veya zümrelere müdahalede bulunulmaması için ikaz edilen meslek gruplarının unvanlarındandir.

bāc-bān ve keştī-bān ve ḳoruğ-bān ve dervāze-bān ve terāzū-bān biy karavul kütevül bir ḥabbe ve bir dinār tama' ve tevakku'kılmasunlar ... 'bâcdâr, gemici, korukçu, kale kapısı muhafizı, tartı memuru, biy, karavul ve kütvel bir dinar (para) ve(ya) bir habbe (bir mal) beklemesin ve ummasınlar"(HY-T14/15).

dīvān bigi: 'Büyük meclis' anlamındaki, Arapça dīvān ile Türkçe bey kelimesinden teşekkül edip ilk kez Timurlular döneminde ortaya çıkan bu makam, dîvân-1 'âlâ' dan sorumlu kişiler için kullanılan bir unvan olmuştur (Şişman 2012: 62). Görev alanları itibarıyla İslam devletlerindeki vezirlik makamına paralel bir konum eden dìvān biginin sorumluluk alanına adlî, askeri ve idarî konular dâhildir. Bu nedenle söz konusu makamdakilerin diyānet-pișe ve emānet-endīşe dindār ve güvenilir (HY-T2/6) kimseler olması gerektiği vurgulanmıştır.

dìvān ve terāzū-bān ve dīvān bigi ve mīr-i tümen ve mīr-āab ve müşrif ve dervāze-bān ve şiğavul ve kütvel korugimāl barça 'ummāl ve duhh̆āl dahl ḳllmasun-lar"divan, tartı memuru, divan beyi, tümen emiri, su emiri, kale kapısı muhafızı, saray teşrifatçısı, kütvel, korukçu, tüm âmil ile dâhiller müdahale etmesinler" (HY-T2/19).

debïr: Sâsânîler ile Fârs ve Hint kültür muhitindeki bazı İslâm devletlerinde kâtib ve münşî anlamına gelen terimdir. Eski Farsçada dipi (yazı), Hindistan'da Prakrit dilinde dipi ve lipi, Orta Farsçada (Pehlevice) dipiver, dipir, dipirih, dibir şekillerinde geçen debîr kelimesi Sümerce dub (levha ve yazı) kelimesinden gelmektedir. Bu Sümerce kelime sonradan duppu, tuppu (levha, sayfa) şekillerinde Akadcaya, oradan da sırasıyla dup şeklinde Ârâmîceye ve def şeklinde Arapçaya geçmiştir. Kelime başlangıçta daha çok debîle ilgili malzeme ve yazı anlamına gelirken sonradan bunları kullanan kişiyi ifade etmeye başlamıştır (bk. Kucur 1994: 63). Türkistan hanlıklarına ait belgelerden bu kişilerin refíc-menzilet debïrlarga yüksek mertebeli kimseler olduğu anlaşılmaktadır.

hükūmet ve kāmrānlıg būstanı-nın bārver eşcārı salțanat ve hükümrānlı̀ gülistānı eşcārı-nın halāvet-bahşs eșmārı ya'nī sa'ādet-mend ferzendleri-bile 'işret-ma'āş karintaşlarga şecā'at ve

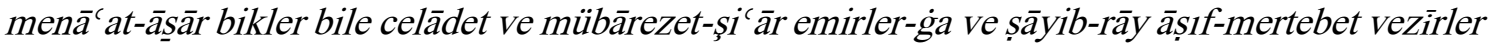

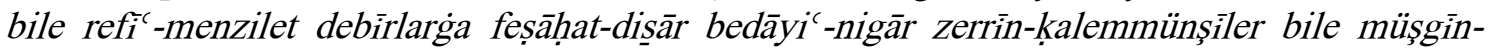
rakam șadākat-şe $<m>$ im dîvānlarga masțūr-1 șadr ve șahïfe olkim ... "egemenlik ve mutluluk bostanının verimli ağaçları, saltanat ve hükümdarlık gülistanı ağaçlarının tatlılık veren bitkisi, yani saâdetli şehzadeler ile işret süren kardeşlere, yürekli ve kuvvetli beylerle yiğit ve mücadeleci emirlere, isabetli görüşlere (sahip, Hz. Süleyman'ın veziri) Âsıf mertebesindeki vezirler ile, yüce makamlı kâtiplere, fâsihlik saçan, güzel suretli, altın kalemli münşiler ile misk kokulu yazılar ve sadakât kokulu (bitiklerin çıktığı) divanlara sadr yazısı ve sahifesi o ki ...”(HY-T55/6).

erbābān: erbāb kelimesi, Arapça bir kelime olup Arapçada, "sahip oldu, 1slahetti, efendi/lider oldu, yetiştirdi ve topladı" anlamları ifade eden "rabbe"sözcüğünün çoğulu olup Türkçe Sözlükte "bir işten anlayan, bir işi iyi yapan kimse" anlamlarıyla geçmektedir (TS 1998:717). Türkistan

\footnotetext{
${ }^{17}$ Detaylı bilgi için bk. (TMEN-II 818 bï, 'Titel für özbekische Stammeshäupter').
} 
hanlıklarına ait tarhanlık yarlıklarında ise halk liderleri için kullanılan bir unvan olarak görülmektedir. Erbāblar, XIX. yüzyılın başlarına kadar, kentsel bölgelerde önemli bir rol oynamıştır. Wood, erbābların Buhara Hanlığında bir tür sulama yetkilisiyken Hive Hanlığında böyle olmadığını, XIX. yüzyılda rollerinin azaldığını, yerini aksakal teriminin almaya başladığını belirtmiştir (2005: 34-35). Türkistan hanlarına ait tarhanlık yarlıklarında akâlarla erbâblar hep bir arada anılmıştır. Bilhassa hanlık işleriningörüşüldüğü Hive Hanlığı divanında erbābların da han, atalık, ınak, vezir, mihter, kuş bigi, divan bigiler gibi bu divanda bulundukları anlaşılmaktadır.

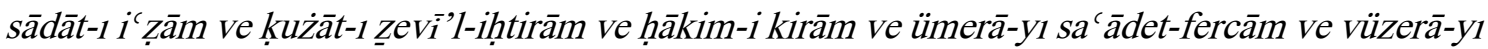
kāfiyü'l-mehām ve mạhremān bārgāh ve șähib-dahlān dergāh ve erbābān ve akayān ve cemīissāḥib-i manṣıbān-1 vilāyet-i H'ārezm ahsena'llāhu aḥvālihum bedānend ki ... 'Harezm vilayetinin makam sahibi bütün efendileri, ağaları, erbâpları, (han) sarayına dâhil olan efendileri, (hanlık) sarayının samimi dostları, yapılması gerekli işleri başaran vezirleri, sonu mutlu (işlere imza atan) emirleri, kerem sahibi hâkimi, hürmetli kadıları, ulu seyyitleri -Allah, onların durumunu güzel k1lsin!- bilsinler ki ..."(Wood 2005: B/4).

hāaib/huccāb: Sasanîler zamanından beri mevcut olan, onlardan sonra İslâm ve Türk-İslâm devletlerine intikâl eden, Arapça bir 1stılahtır. En üstündekilerine hâcib-i kebîr, hâcib-i büzürg, hâcibü'l-hüccâb, melikü'l-hüccâb, uluğ hass hâcib unvanının verildiği hâcib'in mukabili olarak DLT'de tayanğu kelimesi mevcut olup Müslüman Türk devletlerinde hiç rastlanılmayan bu unvana sadece Kara Hitaylarda ve onların Mâverâünnehir'deki hâkimiyetleri esnasında tesadüf edilmektedir (Köprülü 1983: 287-299). Krş. TMEN-III 1369 qāpūčï, 'Türhüter, Türwache' qāāīčì $\leftarrow$ tü. (az.) qapučì id. Türk-İslam devletlerinde sadrazam, vezir ve mabeynci gibi üst düzey devlet görevlilerine verilen bir unvanolup sarayda görevli oldukları, hükümdarlarla görüşmeleri düzenledikleri gibi kabul resmi sırasında herkesi rütbe ve derecesine göre yerlerini tayin eden kişilerdir. Türkistan hanlıklarına ait belgelerde onlardan gökyüzü şekilli mahfilde duran, arslan gibi kükreyip, kaplan gibi bağıran kimselerşeklinde bahsedilmektedir.

hilāfet āsmānı-nı̀ ferhunde hilālı karıntaşlar birle salțanat būstanı-nın huceste nihālı ferzendlerge

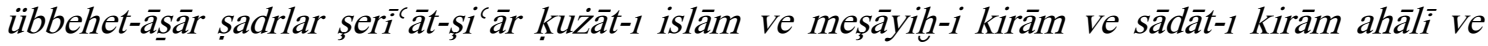
mevālì-i ușūl ve a yā̄n ve esātīn-i bārgāh-1 husrevānī bik-ler muşkīn-rakam münş̧īler diyānet-pişse ve emānet-endịşe dīvānilar arslanlayın akrıp yolbarslayın çaḳırgan mahfil-i sipihr meşākil-de

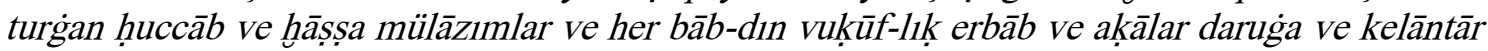

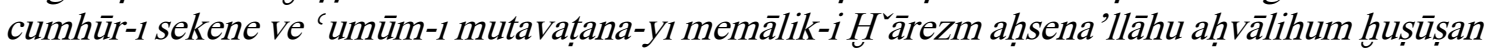
belde-yi Hezāresb-ġa ol-kim 'Harezm memleketlerinin halifelik semasının uğurlu hilali kardeşlerle saltanat bostanının kutlu nihali şehzadelere, azametli sadlar, şerîatı şiâr edinen İslâm kadıları, kerem sahibi şeyhleri, kerem sahibi seyyitleri, ahalisi, efendileri, ayânı, padişahlık sarayının direği beyleri, misk kokulu yazılar yazan münşîleri, dindar ve güvenilir divan (üyeleri), arslan gibi kükreyip, kaplan gibi bağıran, gökyüzü şekilli mahfilde duran hâcipleri, hassa mülâzımları, her bakımdan donanımlı erbâbı, ağaları, darugası, kelanteri, iskân eden halkı ve tüm yurttaşları -Allah, onların durumunu iyileştirsin!- özellikle Hezaresb beldesine o ki ... (HYT2/7), bes makșūd bu mukaddimedin bu kim hürşidd-kadr ve āsmān-bedr karıntaşlar birle hükūmet-penāh sitāre-sipāh berhūrrdār ini ve og̉ullarğa 'ālī-makām ve sa'ādet-fercām diyānet ve şecā' at-l1kssā 'ib-rāy karaçu biy-lerge muşkinn-rakam ve zerrin-kalem müşkinn-rakam dīvānlar birle

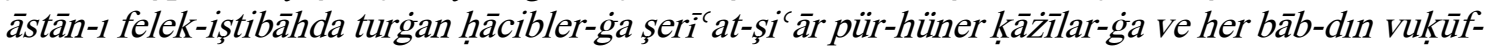
lıg aḳā ve erbāblarğa ve külli 'ummāl-1 sekene-i kubbetü'l-islām H'ārezm hușūṣan Hìvak ah̆sena'llāhu aḥvālihum-ga ol-kim ..."bu mukaddimeden maksud budur ki İslâm'ın kubbesi olan Harezm vilayetinin özellikle Hive['nin]-Allah, onların durumunu iyileştirsin!- güneş rütbeli, gökyüzündeki ay (gibi yüce makamlı) kardeşler ile egemenliğin sığınağı, yıldızlar kadar kalabalık ordusu olan, mutlu küçük kardeş ve şehzadelerine, yüce makamlı, saâdetli, din ve yiğitlik(te) isabetli görüşü olan karaçu beylerine, altın kalemli, misk kokulu yazı(ların çıktığı) divanlarla, gökyüzünü andıraneşikte duran hâciplerine, şerî‘atı şiâr edinen, hünerli kadılarına, her konuya vakıf ağa ve erbaplarına, (burada)iskân eden bütün âmillerine o ki ...”(HY-T14/7). 
hākim: Hanlık topraklarının eyaletlere ayrıldığı Türkistan hanlıklarında eyaletleri idare eden valiler için kullanılan, Arapça bir unvandır. Eyalet idarecisi olan hâkimler genellikle biylerin kimi zaman ise atalık unvanını kullandıkları tespit edilmiştir. Ayrıca hâkimler bek ve nayib unvanıyla da yöneticilik yapmışlardır (Şişman 2012: 62). İncelemeye esas alınan belgelerden bu unvanın, şehir idarecileri için kullanıldığı anlaşılmaktadır.

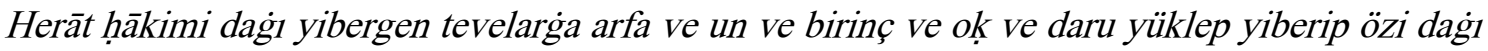
Mìr Ahmed Hān bile mollā katlaşıp Meymene hākimi ve Fìrūz-ı Kūh ḥākimi özleri-nin barça leşkeri ve top ve top-hānesi bile biz-nin hiżmetimiz-ga kilmekçi bolganlan-nın haberikildi 'Herat hâkimi de gönderdiği develere arpa, un, pirinç, ok ve daru yükleyip kendisi de Mir Ahmed Han ile molla gönderip Meymene hâkimi ve Friruz-1 Kûh hâkimi kendilerinin tüm askeri, top ve tophanesi ile bizim hizmetimize gelmek niyetinde olduklarının haberi geldi” (Hin-T4/11).

hān: Türkistan hanlıklarında hanlığın başındaki kimseler için şahıs adlarından hemen sonra kullanılan bir unvan. ${ }^{18}$

Abū'l-muzaffer ve'l-manșūr Anūş̧a Muhammed Bahādur Hān sözümiz 'husret ve zaferin babası Anuşa Muhammed Bahadır Han buyruğumuz" (HY-T1/2), abü'l-fath ve'l-manșūr Seyyid Yādigār Muḥammed Bahādur Hān sözümiz "nusret ve fethin babası Seyyid Yadigâr Muhammed Bahadır Han buyruğumuz" (HY-T5/1), Abū'l-gāāzi Seyyid Muhammed Bahādur Hānn sözümiz 'Ebû'l-gazi Seyyid Muhammed Bahadır Han buyruğumuz" (HY-T6/1), abū'l-muzaffer ve'lmanșūr abū'l-feth Seyyid Muḥammed Raḥim Bahādur Hān sözümiz 'Nusret ve zaferin babası Ebû'lfeth Seyyid Muhammed Rahîm Bahadır Han buyruğumuz”(HY-T67/2).

kātib: Sözlükte Arapça ketb 'yazmak' fiilinden türetilmiş bir ism-i fâil olan kâtip (kâtib, çoğulu küttâb, ketebe) 'yazı işleriyle uğraşan kimse, sekreter, yazıcı; bilgili kişi, noter; muharrir' demektir (Küçükaş̧̧ı 2002: 53). Yazışma belgelerinde bahşs, bitikçi, bitkeçi, debir, muharrir, müdebbir, münşsi, țayşı kelimeleri ile birlikte yazıcılar için kullanılan kelimedir.

bākiyyetü'l-yavlar hezimet kılıp andan mürāca'àt kılıp Çim-kent-ke nüzūl itip anca ki kātiblerimiz-ni serişte ve mükemmel eylep yene Urusiyye üsti-ga yürmak bolup ... 'kalan düşman hezimete uğrayıp oradan geri dönerek Çimkent'e nüzul etmiş. Oradaki kâtiplerimizi serişte ve ve mükemmel k1lıp tekrardan Rusya üzerine yürümek" (HoBH-T1/15-16).

mirrze: Menşeinin Farsça olduğu bu kelimehan soyundan gelen anlamında kullanılan "emîrzâda $>$ mìr+zâde $>$ mïrzā" kelimelerinin birleşmesiyle teşekkül etmiş bir unvandır (Özyetgin 2005: 80). Türkistan hanlıkları sahasına ait belgelerde toplumun ileri gelenleri ve hanlık görevlileri tarafından şahıs adlarından önce kullanılan bir unvan olarak karşımıza çıkmaktadır. Mirza mahkeme zabıt kâtibi demektir. Kur'ân-1 Kerîm'de alım-satım, kiralama gibi akitlerle ilgili belgelerin "adil kâtibler/kâtib-i adl" tarafindan düzenlenmesi istenmektedir. Hokand Hanlığı'nda mirzalık görevine hukukî muâmelerle ilgili belgeleri düzenleyebilecek vasıflara da sahip kimseler tayin edilebilirdi. Bu sebeple mirza olarak tayin edilen kimse görev yaptığı mahkemede zabit kâtipliği yanında bir noter gibi belgeleme işini de yürütüyordu.

türli mu'āmele körsetmekke kabūlınız bolsa yāki biz-nin memleketümizdegi işni tafsil ḳılsanız ve şol toginga hem Mïrze Hākim Bay teyerlik ve keyin i'tibārlandurgen ve imperator-1 a'zām hażret-lerine meni hürrmet kılgaydın Mïrze Hākim Bay bilen yiberüle turgan tuhfe ve hediyelerni icābet kılmakga ümìd tutarmız ki biz pādșāh ihlāșını hürmet kılıp yād-nāme bilüp özleri-nin ulug ve kāadir hem-sāyesiga mürüvvet ve iltifăt körgüzgeyler 'türlü muamele(ler) göstermeye kabulünüz olsa veya bizim ülkemizdeki işi tafsil etseniz, o doğrultuda hem Mirza Hâkim Bey değerli, ardından (da) itibarlandıradurmuş, (hem de) yüce imparator hazretlerine beni saygın kılacağından Mirza Hâkim Bay ile gönderileduran armağan ve hediyeleri icabet ettiğine ümit

${ }^{18}$ Detaylı bilgi için bk. (hāan TMEN-III 1967: 1161; Kök 2020: 242-243). 
ederiz ki biz padişah ihlâsını saygın kılıp hatıra yazısı bilip kendilerinin ulu ve kudretli gölgesine mürüvvet ve iltifat gösterecekler" (HoBR-T2/21).

kelānterān: Ferman veya yarlığın verildiği kimsenin ya da muhatap olacağı kimselerin adları ile meslek gruplarının adlarının sıralandığı bölüm olan inscriptio bölümü ile sanctio et corroboratio (te'kîd, teyîd) bölümlerinde geçen Farsça bir birleşik sıfat olan kelân-ter kelimesinin cem 'idir. Lambton, kelânterin Selçuklularda olduğu gibi reisin benzeri bir rütbe olduğunu ifade etmektedir. Ona göre kelanter, bölgenin bir nevi temsilcisidir. Ancak Selçuklulardaki reisten yetki dairesinin daha geniş olduğu kanısındadır (İA, 2002: 203). Hasanzâde'ye göre kelanterler; divanî memurların ve darugaların esnaf ve halktan vergi toplama işlerindeki yardımcılarıydı (Hasanzâde 2001: 213). Bu makamın görevi hakkında kesin ve net bir tarif verilmese de dönemin kaynaklarından yola çıkarak devlet bürokrasisinin alt katmanlarında yer aldığını tahmin etmek mümkündür.

hilāfet āsmānı-nı̄ ferhunde hilālı karıntaşlar birle saltanat būstanı-nı̄ huceste nihālı ferzendlerge

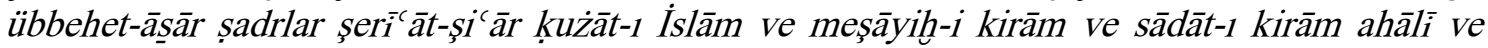

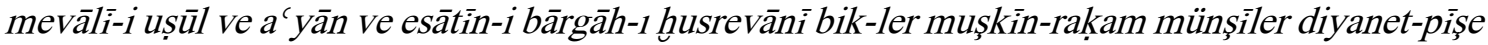
ve emānet-endīşe dīvānilar arslanlayın aḳı yolbarslayın çakıığan maḩil-sipehr meşākil-de

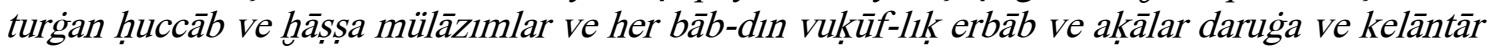
cumhūr-1 sekene ve 'umūm-1 mutavațana-yı memālik-i H'ārezm aḥsena'llāhu aḥvālihum huușụsan belde-yi Hezāresb-ġa ol-kim 'Harezm memleketlerinin halifelik semasının uğurlu hilali kardeşlerle saltanat bostanının kutlu nihali şehzadelere, azametli sadlar, şerîatı şiâr edinen İslâm kadıları, kerem sahibi şeyhleri, kerem sahibi seyyitleri, ahalisi, efendileri, ayânı, padişahlık sarayının direği beyleri, misk kokulu yazılar yazan münşîleri, dindar ve güvenilir divan (üyeleri), arslan gibi kükreyip, kaplan gibi bağıran, gökyüzü şekilli mahfilde duran hâcipleri, hassa mülâzımları, her bakımdan vakıf erbâbı, ağaları, darugası, kelanteri, iskân eden halkı ve tüm yurttaşları -Allah, onların durumunu iyileştirsin!- özellikle Hezaresb beldesine o ki ...”(HY$\mathrm{T} 2 / 8)$.

münşi:: Meydana getirme, yapma, bina etme; yazma, kaleme alma; düzyazı anlamlarındaki Arapça inşâ (Kanar 2009: 1581) kelimesinin, ism-i fâili olan münşîi için sözlükte 'inşa eden, kuran, yapan; edebî kurallara göre yazı yazan, güzel üsluplu kâtip'(Kanar 2009: 2399) açıklamaları yer almaktadır. Türkistan hanlıklarında hanlık işlerinin yürütüldügü kuruma divan, bu kurumdaki yazışmaları yürüten özel kâtip, yazıcılara ise münşī adı verildiği anlaşılmaktadır.

behrām -șavlet bigler birle refíc- menzīlet-lik șadrlarg̉a kim 'iṣmet mülkige bānī ve pādșāhlık şevketi-nin nigeh-bānı irürler șăhib-hibret emānet-şi ${ }^{\top} \bar{a} r$ vezīrler birle șāyib fikret bā-i' tibār münşi-lerg̉a kim eyālet memāliki-nin 'adālet-pīşesi ve șevket kişveri-ni<n>g hayr-endīşesi tururlar "Merih savletli beylerle yüce menzilli sadrlara ki (onlar) ismet mülkine mimar ve padişahlık şevketinin gözcüsüdürler. Tecrübe sahibi, güvenilir vezirlerle, isabetli fikirleri olan, saygın münşilere ki eyalet memleketlerinin adalet başçısı, şevket ülkesinin iyilik düşünenidirler"(HY-T6/4).

og̉ul oġlan: Türkçenin bilinen ilk yazılı belgelerinden itibaren çocuk için kullanılan bu kelime, ilerleyen süreçte anlam daralmasına uğrayarak sadece erkek çocuk için kullanılmıştır (Ata 2008: 194). İdarî teşkilata ait bir unvan adı olarak ise Cengiz Han nesline mensup, tahta çıkamamış şehzadeler için kullanılmıştır. Timürlü, Karakoyunlu, Akkoyunlu, Safavî ve Tiflis Hanlığı'na ait Farsça fermanlardaki ferzendān(Kök 2020; 436, 487, 529, 718, 1697) kelimesine tekabül etmektedir. ${ }^{19}$ Türkistan hanlıklarına ait belgelerde de bu anlamıla kullanıldığı tespit edilmiştir.

bes bu mukaddima [hūurşid-ḳadr] [ve] āsmān-bedr ḳarıntaşlar-ġa ve hükūmet-penāh sitāre-sipāh

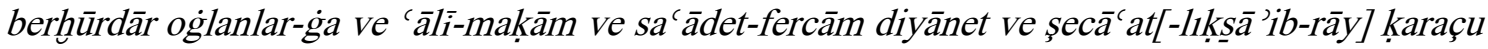
biylerge muşkinn-rakam ve zerrīn-kalem mülk-ārāy ve șāḥib-rāy ferāset-lık dīvānlarga siyāset ve heybet-lık arslan-layın [akrıp] yolbarslayın çakıırgan āstān-ı felek-iştibāhda turğan ḥācibler-ğa ve

\footnotetext{
${ }^{19}$ Detaylı bilghi için bk. (TMEN-II 1965: 502 og̀lān).
} 


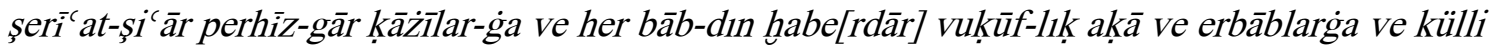
'ummāl-1 sekene-i kubbetü'l-istām H'ārezm husūṣsan hezār-esb ahsena'llāhu ahvāāihum-g̀a olkim 'İslâm'ın kubbesi olan Harezm vilayetinin güneş rütbeli, gökyüzündeki ay (gibi yüce makamlı) kardeşlerine, egemenliğin sığınağı, yıldızlar kadar kalabalık ordusu olan, mutlu şehzadelerine, yüce makamlı, saâdetli, din ve yiğitlik(te) isabetli görüşü olan karaçu beylerine, misk kokulu yazı ile altın kalemi ile memleketi süsleyen, isabetli fikir, ferasetli divanlarına, siyaset ve heybetli arslan gibi kükreyip kaplan gibi bağıran, gökyüzünü andıraneşikte duran hâciplerine, şerî‘atı şiâr edinen, dindâr kadılarına, her bakımdan haberdar ağa ve erbaplarına, bütün iskân eden âmillerine özellikle Hezaresb'e -Allah, onların durumunu iyileştirsin!- o ki ..."(HY-T4/5).

șadr: Arapça 'göğüs' anlamına gelen șadr, başlangıçta seçkin kişiler için kullanılan onursal bir unvan idi. XIII. yüzyıldan itibaren önem kazanan bu unvan, İlhanlılarda, özellikle İran dünyasında dinî işlerden sorumlu bir memuriyet için kullanılmaya başlanmıştır (Horst 1956: 17). Timürlüler zamanında dinî, en üst makamdaki yetkiliyi ifade etmede kullanılan bu terim, Timür'ün halefleri döneminde de şehirlerde dinî otoriteyi elinde tutan imam ve reisler için kullanıldığı görülmüştür (Yüksel 2009: 144-145). Türkistan hanlıklarına ait yarlıklarda protokolde hanın kardeşleri ve şehzadelerden sonragelen en önemli bir makam olduğu anlaşılmaktadır. İncelenen belgelerde onlardan sadrazamlıktan ayrılmış kimselerin unvanı anlamındaki (Devellioğlu 1990: 1353) übbehet-āșār büyüklük, ululuk sahibi (HY-T2/5) kimselerşeklinde bahsedilmektedir.

behrām-șavlet bigler birle refí'-menzīlet-lik șadrlarğa kim 'ișmet mülkige bānī ve pādșāhlık șevketi-nin nigeh-bānı irürler șāhib-hibret emānet-și' ār vezīrler birle șāyib-fikret bā-i' tibārr münşi-lerga kim eyālet memäliki-nin’ 'adālet-pīşesi ve şevket kişveri-ni $<n>g$ hayr-endişsesi tururlar 'Merih savletli beylerle yüce menzilli sadrlara ki (onlar) ismet mülkine mimar ve padişahlık şevketinin gözcüsüdürler. Tecrübe sahibi, güvenilir vezirlerle, isabetli fikirleri olan, saygın münşilere ki eyalet memleketlerinin adalet baş̧̧ısı, şevket ülkesinin iyilik düşünenidirler" (HY-T6/4).

șāhib-daḩl: 'Sâhip, bir vasfi olan, koruyan, bir iş yapmış olan' anlamındaki Arapça șāḥib (Devellioğlu 1990: 1093) ile 'girme, karışma; nüfuz' anlamlarındaki, Arapça dah̆l (Devellioğlu 1990: 194) kelimesinin birleşmesinden teşekkül etmiştir. Türkistan sahasına ait belgelerde dergāh-1 'ālem-penāholarak nitelendirilen hanlık divanı üyelerinden biri oldukları anlaşılmaktadır. Emir Timür'un, seyitler soyuna mensup Ebu Müslim'in evlatlarına verdiği 780/1379 1380 tarihli inayetnâme yarlığında ınak-lar ve atalıklar ve taksavullar ve çağdavullar

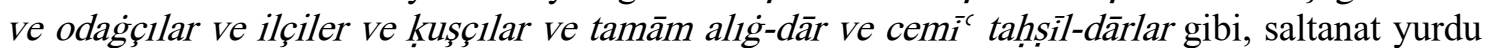
Harezm'in ameldârlarından olduğu anlaşılmaktadır (Kök 2020: 424-425). Benzer görevinin Türkistan hanlıkları döneminde de devam ettiği görülmektedir.

hayr-endīş umerālarga șạhid-tedbìr vüzerā birle zerrīn-kalem ve muşkīn-rakam dīvānlarga dergāh-1 'ālem-penāhda turgan șạhib-dahllar birle mahremler-ga husūụsan Ȟārezm-i irem-bezm

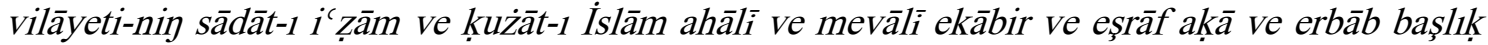
barça 'ameldārlariġa masțūr șudūr-1 șahïfe ol kim ..."hayır düşünen emirlere, tedbir sahibi vezirler ile altın kalemli, misk kokulu yazı(nın yazıldığı) divanlara, âlemin sığınağı olan dergâhta duran sâhip-dahller ile samimi (dostlara), özellikle cennet meclisi(ni andıran) Harezm vilayetininulu seyyitleri, İslâm'ın kadıları, ahali, efendi, ulular, eşrâf, ağa, erbap, başçı (ve) bütün vergi tahsildarlarınayazılan sahifenin satırları bu(dur) ki ..." (HY-T66/4).

töre: Clauson, sözcüğün Moğolcadan ödünçlenmiş olabileceğini ileri sürmüştür (Clauson 1972: 531b-532a). Räsänen, Moğolca töre 'tavır, tutum' ve Türkçe törü arasındaki benzerliğe vurgu yapmıştır (1969: 495a). Pelliot, törü kelimesini Çinceyle ilişkilendirmiştir (TMEN-I 134). Hamilton, kelimenin Türkçedeki törü- (veya saymaca tör-) 'yaratılmak, oluşturulmak' fiiline ü fiilden ad yapım eki getirilerek oluşturulduğu görüşündedir (Hamilton 1998: 226). Doerfer törö kelimesinin Türkçeden Moğolcaya geçtiğine işaret etmiştir (TMEN-I 543). Sözcük, törü>töre biçimlerinde ve 'töre, gelenek, kanun, öğreti, din' gibi anlamlarla tarihî Türk yazı 
dillerinin tamamında görülür. Törü günümüzde kuzeybatı Türk lehçeleri ile Oğuzcanın yayılma alanlarında varlığını sürdürmektedir (Clauson 1972: 531-532). Türklerin eski zamanlarından kalan temel politik terimlerden biri olan, il ve kağan kelimeleri ile ilgili (Kök 2019: 36) olan kelime, Türkistan hanlıklarına ait tarhanlık yarlıklarında hanzâde ve beyzâdeler için kullanılan bir unvan olarak karşımıza çıkmaktadır.

ḥażret-i cennet mekānì bile Mūsā Töremiz-nị istịhvānları kilgeç Gendūmkān ḥavlige tüşürüp üstilerin yahşı becerip caylasunlar "cennet mekân hazret ile Musa Töremizin dostları geldiklerinde avluya konup üstlerini güzelce temizleyip yerleştirsinler" (Bregel 2007: 27/3).

vezīr: İslâm devlet teşkilatında halife veya hükümdarlardan sonra gelen, yüksek rütbeli kimseler için kullanılan Arapça unvan (Devellioğlu 1990: 1382). İlk Türk devletlerinde konuşan ve önerilerde bulunan kişilerin makamı anlamındaki ayġuçı (Clauson 1972: 271a), Karahanlılar dönemindeki kengeşçi, öge (Yağlı 2014: 32) kelimelerinin muadilidir. Kâtiplik ve danışmanlık istidadı taşıması gereken vezirlik makamı, Türkistan hanlıklarında da mevcuttur. Türkistan hanlarına ait belgelerden bu rütbeye sahip kimselerin tecrübe sahibi, güvenilir șăhib-i hibret ve emanet-şi ${ }^{\complement} \bar{a} r$ vezīrler (HY-T1/10, HY-T3/5, HY-T5/5, HY-T6/4, HY-T7/6) olmas1 gerektiği anlaşılmaktadır.

șāhib-[hibret emānet-şi ${ }^{i} \bar{a}$ r] vezirler birle șāyib-fikret bā-i' tibār münşī-lerğa kim eyālet memālikinin 'adālet-pişsesi ve şevket-i kişveri[-nin hayr-endişesi tururlar]... "tecrübe sahibi, güvenilir vezirlerle, isabetli fikirleri olan, saygın münşilere ki eyalet memleketlerinin adalet baş̧̧ısı, şevket ülkesinin iyilik düşünenidirler" (HY-T7/6).

bahādur: 'Kahraman, cengâver ve yiğit' anlamlarına gelen ve Çingizli fütuhatından sonra geniş bir alana yayılarak Türk hükümdarlarının resmî unvanları arasında yer alan, Moğolca bu unvan; Farsça, Urduca, Lehçe ve Rusçaya geçmesinin yanı sıra tarihî ve çağdaş Türk dili alanında bagatur (Proto-Bulgarlar), bahadır, batur, batır, matur (Çağatay, Kırgız, Kazak, Kazan ve Başkırt lehçelerinde), pattır (Çuvaşçada), pettır, mettir (Altaycada) şekillerinde ve Yenisey Ostyakları'nda baha, Macarcada da bator ş̧eklinde mevcuttur (Köprülü 1983: 173-177). Köklerinin çok eskilere dayandığı sözüm, sözümiz, süyüzümiz formüllerinden önce, yarlık veya fermanı veren hükümdarın adından ise hemen sonra İlhanlı, Celayirli, Timürlü, Karakoyunlu, Akkoyunlu, Safavî ve Osmanlı Devletlerinin yanı sıra Altınordu, Kazan, Kırım ve Türkistan hanlıkları diplomatikasında da kullanılan bir formüldür. ${ }^{20}$

Abū'l-muzaffer ve'l-manșūr Anūşa Muḥammed Bahādur Hān sözümiz 'husret ve zaferin babası Anuşa Muhammed Bahadır Han buyruğumuz"(HY-T1/2), abū'l-fath ve'l-manșūr Seyyid Yādigār Muhammed Bahādur Hān sözümiz "husret ve fethin babası Seyyid Yadigâr Muhammed Bahadır Han buyruğumuz'(HY-T5/1), Abū'l-g̀āzi Seyyid Muhammed Bahādur Hān sözümiz 'Ebû'l-gazi Seyyid Muhammed Bahadır Han buyruğumuz"(HY-T6/1), abü'l-muzaffer ve'l-manșūr abü'l-feth Seyyid Muhammed Raḥim Bahādur Hān sözümiz 'Nusret ve zaferin babası Ebû'lfeth Seyyid Muhammed Rahîm Bahadır Han buyruğumuz"(HY-T67/2).

h้ॅ̄āce: Yeni Farsçada X. yüzy1ldan beri "efendi, sâhip, kâtip, muallim, tüccar" gibi türlü anlamlardaki bu kelime; Farsçadaki anlamlarıyla eş değer bir şekilde uzun süreden beri tarihî ve çağdaş Türk yazı dillerinde hoca şeklinde tanıklanmaktadır. Bu unvanın toplumsal ve idarî teşkilatta vazifeli kimselere verildiği görülse de Gazneli, Selçuklu, İlhanlılarda hükümdardan sonra devletin en büyük rüknü olan vezire hâce-i büzürg, Harezmşahlarda hâce-i cihândiğer devlet ricaline ise hâce denilirdi. Selçuklu veziri Nizâmü'l-mülk'ün Siyasetnâme adlı eserinde 'devlet dairelerinde çalışan memurlar, yani bürokratlar' için hâce ve hâcegân kelimelerinin kullanıldığı görülmektedir. Timürlü, Karakoyunlu ve Akkoyunlu döneminde bürokratlar için kullanılmaya devam eden bu unvan, Safavîlerin kuruluşundan sonra İran'da eski önemini yitirse de Hindistan ve Türkistan coğrafyasında muhafaza etmeyi başarmıştır. Türkçede şahıs isimlerinin önüne veya

${ }^{20}$ Detaylı bilgi için bk. (bahādur TMEN-II 1963: 817). 
sonuna eklenen bu unvanın (Köprülü 1983: 280-287) Türkistan hanlığı belgelerinde şahıs adlarının önüne geldiği görülmektedir. Hanlık topraklarındaki seyitlerin de bu unvanı kullandıkları tespit edilmiştir.

müşsterī hāṣsiyyet Cemşid āyīn karintaşlar birle sitāre sipāh ber-hüurdār ferzendlerke 'ālì himmet Behrām-șavlet bigler birle refí menzilet-lik șadrlar-ge zerrin kalemve müşsiñ rakam dīvānlarge

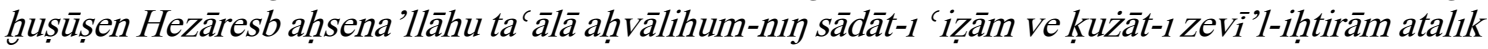
ve nāyib akā ve erbāb barça 'ameldārlarig̀a olkim cenāb-1 siyādet-penāh hidāyet-destgāh merhumūi

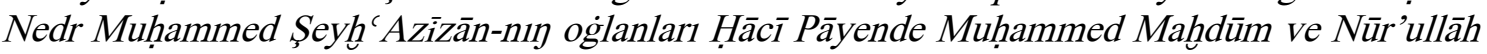
Mahdūm ve 'Abdu'llāh Mahdūm ve 'Abdu'l-hayy Mahdūm merhūmīinin og̀lanları ve cenāb-1

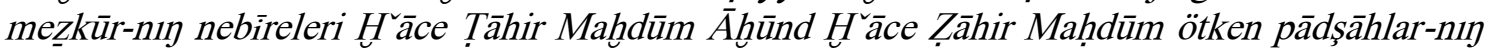
nişānların zāhir kılıp imżā iltimās kıldılar irse biz takı merāhimim-i hü̈srevāne-mizni

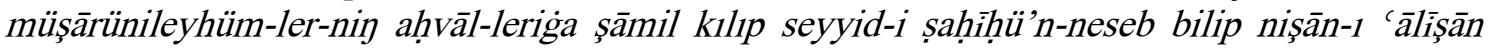
soyurgal kılduk "Jüpiter hâsiyetli, Cemşîd töreli kardeşler ile yıldızlar kadar kalabalık ordusu olan şehzadeler, yüksek himmetli, Merih savletli beylerle yüce menzilli sadrlara, altın kalemli ve misk kokulu divanlara özellikle Hezaresb'in -Allah, onların durumunu güzelleştirsin!- ulu seyyitleri, hürmetli kadıları, lala, nâip, ağa, erbap ve bütün ameldârlarına o ki seyyitliğin sığınağı, hidayetin destgâhı olan merhum Nedr Muhammed Şeyh Azizan cenabının oğulları Hacı Payende Muhammed Mahdum, Nurullah Mahdum, Abdullah Mahdum, Aldulhay Mahdum merhumunun oğulları ve adı geçen cenabın torunları Hace Tahir Mahdum, Ahund Hace Zahir Mahdum mazideki padişahların (kendilerine verdiği) nişanlarını gösterip imza istediklerinde biz de padişahâne merhametlerimizi adı geçenlerin durumlarını kapsayıp, hakîkî seyyit nesepli bilip şanı büyük nişan(ımızla kendisini) soyurgal kıldık"(Wood 2005: D/7).

\subsection{Diplomasi ile İlgili Meslek ve Unvan Adları}

barğuçı ve kilgüçi: 'gitmek' (Clauson 1972: 354a-b) anlamındaki bar- ve 'gelmek' (Clauson 1972: 715b) anlamındaki kil- fiilinin- $\dot{g} u /-g \ddot{u},-k u /-k \ddot{u}$ sıfat-fiil ekinin addan ad yapma eki $+c ̧ 1 /+c ̧ i$ ile genişletilmiş biçimleridir. Eraslan, ekin gelecek zaman ifadesi yanında şimdiki zaman ve devamlılık ifadesi de taşıdığını belirtmektedir (1980: 91). Bayraktar ise eki, geniş zaman ifadesi taşıyan sıfat-fiil ekleri başlığı altında göstermiş; ancak ekin gelecek zaman ifadesi taşıdı̆̆ını belirtmiştir (2004: 87). İncelenen belgelerde ekin, geniş zamanda gerçekleşen ve fâil adlar teşkil eden kelimeler türettiği görülmektedir. Türkistan sahasına ait tarhanlık yarlıklarında barġuçı ve kilgüçi biçiminde çift söz olarak kullanılan bu kelime, İran sahasında kurulan Türk devletlerine ait Farsça yazışmalardaki āyende ve revende kelimelerine yani diplomatik heyete veya gelip giden misafirlere tekâbul etmektedir. Bu kimselerin Türkistan hanlığı arazilerindeki mükelleflerin evlerine konuk olup onlardan konalga ve süysün(erzak vergisi) talep edebildikleri veya gele karaları diye adlandırılan hayvan sürülerinden ulag (hayvanı ya da vergisi) tutabildikleri anlaşılmaktadır.

ilçi ve yolçı barğuçı ve kilgüçi ve cemī‘ iş ve küç üstünde yürgen ḳonalga ve süysün tilep gele karalarıdın ulag tutmasunlar "elçi, yolcu, giden ve gelen ve bütün hizmetliler; konalga ve süysün (vergisi) dileyip sürü ve hayvanlarından ulag (hayvanı) tutmasınlar" (HY-T3/12), ilçi ve yolçı barğuçı ve kilgüçi at ve tivelerin ulag tutup konalga ve süysün tilep ivlerige tüşmesünler "elçi, yolcu, giden ve gelen; at ve develerini ulag (hayvanı) tutmasınlar, konalga ve süysün dileyip evlerine (zorla) misafir olmasınlar" (HY-T4/9), ilçi ve yolçı barğuçı ve kilgüçi ivlerige tüşüp konalg̀a süysün tilemesünler "elçi, yolcu, giden ve gelen; evlerine varıp konalga ve süysün (vergisi) dilemesinler" (HY-T1/17).

ilçi: Bir devleti başka bir devlet nezdinde temsil eden kimse, sefir; bir uzlaşma sağlamak veya işi bitirmek için birinin yanına gönderilen kimse; yalavaç, peygamber, resul, nebi. Clauson, "yabancı ülkelerde hükümetin, ülkenin temsilcisi" anlamına gelen bu kelimenin memleket, ülke anlamlarına gelen el iladından addan ad türetme eki +çI ile türetilmiş bir kelime olduğunu belirtir (1972: 129a). Schönig "delege, diplomatik temsilci, elçi” anlamlarına geldiği ve delege, elçi, kurye, misyoner (Lessing, 307a) sözcüğünden ödünçleme olduğunu dile getirir(1960: 94- 
95). ${ }^{21}$ İncelenen belgelerde yolçı kelimesi ile bir arada kullanılan ilçilerin, Türkistan hanlığ arazilerindeki mükelleflerin evlerine konuk olup onlardan konalga ve süysün(erzak vergisi) dileyebildikleri veya gele karaları diye adlandırılan hayvan sürülerinden ulag (hayvanı ya da vergisi) tutabildikleri anlaşılmaktadır.

ilçi ve yolçı barg்uçı ve kilgüçi ve cemī' iş ve küç üstünde yürgen ḳonalga ve süysün tilemesünler gele karaların ulag tutmasunlar "elçi, yolcu, giden ve gelen, iş ve güç (hizmet yükümlülügü) üzerinde duran; konalga ve süysün (vergisi) dilemesinler, sürü ve hayvanlarını ulag (hayvanı) tutmasınlar" (HY-T3/12), her yerge sūdāga barsalar ve kilse-ler karavul ve çihil-yekçi ve dervāzebān ilçi ve yolçı dāhil ve muzāhim bolmasunlar "her nereye ticarete gitseler ve gelseler karavul, kırkta bir vergi tahsildârı, kale kapısı muhafızı, elçi ve yolcu müdahil olmasınlar ve zahmete sokmasinlar" (HY-T15/15).

tavaçı: Ortaçağ' da bazı Türk ve Moğol devletlerinde kullanılan bir tür askerî unvan olup Moğolca 'saymak, toplamak, hesaplamak' anlamındaki togacadan gelmektedir (TMEN-I 260-264; Lessing 1960: 1255). Çağatay Türkçesinde 'ulak dimekdür, ba' żllar deve ile sekirden ulaḳdur dimişler' (Güzeldir 2002: 232) şeklinde izah edilmektedir.

anı̀ üçün Mollā Muhammed Baba Halīfe-ni atası-nı ve ini-si 'Iyd Muhammedni ve karıntaş-lanı Veys Muhammed ve Rūzūm-nı ve og̀lanları birle tarhan ve merfü' u'l-ḳalem kılıp nişān-1 soyurgàal kılduk imdi bu humāyūn yarlıg körgeç ehl-i kalem ḳalem-lerin ve 'ameldārlar kadem-lerini tartsunlar ve munlar her yerde ikin ikse-ler bīgār ve haşar ve ḳazu ve kaçu buyurmasunlar Hive-

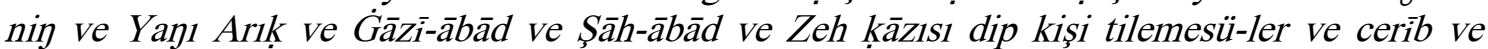
tanābāne ve algut ve salgut tip nimerse tilemesün-ler ve at baǵlatmasunlar ve miltık salmasun-lar ve araba almasunlar ve ipek-leridin māl almasun-lar avda ve çerik-de atlanursın dimesün-ler ve at tilemesünler ilçi ve yolçı barguç̧ı ve kilgüçi ve tavaçı üylerige tüşüp ḳonalga ve süysün tilemesünler "onun için Molla Muhammed Baba Halife'yi babası ve küçük erkek kardeşi İyd Muhammed'i ve kardeşleri Veys Muhammed ve Ruzum'u, oğullarıyla birlikte tarhan ve (üzerlerinden bütün vergi) kalemlerini kaldırıp soyurgal nişanı verdik. Şimdi bu hanlık yarlığını gördüklerinde kalem ehli (mutasarrıflar onlar üzerinden vergi) kalemlerini kaldırsınlar, bütün vergi tahsildarları (da) ayaklarını (onların arazilerinden) çeksinler. Bunlar her nerede ekin ekseler (onlara) bīgār, haşar, kazu ve kaçu (vergisi ve yükümlülüğü) buyurmasınlar. Hive'nin, Yeni Arık, Gaziabad ve Zeh (bölgesinin) kadısı diye adam talep etmesinler. Cerīb, țanābāne, alğut ve salg̈ut (vergisi) adı altında bir şey istemesinler, (arazilerine) at bağlatmasınlar, tüfek attırmasınlar, araba almasınlar, ipeklerinden māl (vergisi) almasınlar, avda ve (merada hayvan otlatırken) ata biniyorsun demesinler ve at istamesinler. Elçi, yolcu, giden gelen, tavacı; evlerine (zorla) misafir olup konalga ve süysün (vergisi) istemesinler" (HY-T2/18).

yolçı: Türkistan hanlıklarına ait tarhanlık yarlıklarında ilçi, yolçı, barg̉uçı ve kilgüçi meslek adlarıyla birlikte kullanılan bir meslek adıdır. 'kılavuz, rehber' anlamlarındaki kelimenin kökünü meydana getiren yol, günümüzdeki karşılığıyla, birtakım ses değişmelerine uğramış biçimde Türkçenin gelişme ve yayılma alanlarının tamamında tanıklanmaktadır (Clauson 1972: 917a-b); Farsça, Moğolca, Tunguzca, Güney Sibirya dilleri, Doğu Sibirya dilleri ve Sırpçaya da girmiştir (TMEN-I 226-227). Kelime ilk defa Eski Uygur Türkçesi metinlerinde 'kılavuz' anlamında kullanılmıştır(Clauson 1972: 921b). Semih Tezcan, Kutadgu Bilig dizininde 'yolcu' olarak anlamlandırılan yolçı'nın (Arat 1979: 552) 'kılavuz, yol gösterici' anlamının alınması gerektiğini dile getirmiştir (1981: 76). Harezm sahası metinlerinde de 'rehber, kılavuz' anlamını koruyan yolçı, (Ata 1997: 744) Türkçe'nin sonraki dönemlerinde genellikle 'yolcu, gezgin' karşı1lığıyla görülür (Clauson 1972: 921b). Türkçeden Farsçaya yolçı 'kılavuz'; Moğolcaya jolşu 'yolcu'; Sırpçaya jolĵija 'yolcu' biçimlerinde geçen sözcük (TMEN-IV 225) günümüzde 'kılavuz' kullanımıyla bağlantılı olarak Kırgız Türkçesinde colçu telaffuzuyla "kılavuz" anlamıyla yaşamaktadır (Yudahin 1998: 220). İncelenen belgelerde yolçının ilçi kelimesi ile birlikte kullanılması, Türkistan hanlıkları elçilik heyeti arasında onları zor

\footnotetext{
${ }^{21}$ Detaylı bilgi için bk. (TMEN-II 656 élçī)
} 
geçitlerden, sarp dağlardan, tehlikeli yollardan geçirmekle görevli kimselerin de yer aldığı anlaşılmaktadır.

ilçi ve yolçı ve barg̉uçı ve kilgüçi ve cerīb dīvāni ivlerige tüşüp konalġa ve süysün tilemesünler "elçi, yolcu, gidip gelen ve divan cerîbi evlerine (zorlarına) misafir olup konalga ve süysün (vergisi) istemesinler" (HY-T7/12).

\subsection{Esnaf ve Zanaatkârlık ile İlgili Meslek ve Unvan Adları}

kayrakçı: Türk dilinde kayra- 'bilemek, keskinleştirmek' (Clauson 1972: 605b), kayrak 'bileği taşı' (UTİL 1999: 794a), kayrakçı da 'bileğici' anlamlarına gelmektedir. İncelemeye esas alınan Türkistan hanlıklarına ait belgelerde Ata kulı adlı birisinin mesleği olarak karşımıza çıkmaktadır.

Nahşs-Murād Daruğa ve Hasan Tarağçı ve Ata ḳulı Kayrakçı ve Usta 'A vaż Niyāz ve Baba Cān ve'Abdu'r-rahmān Kelek ve Baba Cān Harătve Muhammed Cān Sūfì ve șimālen 'Așūur Muhammed ve Baba ve Ya' kūub Bay ve Raḥmān-birdi ve ba' $\dot{z} ı$ mezkū̄r darugia ve 'Abdu'rrahmmān Kelek ve ba' ̇̇i-s1 Zeh-keş ve garben Zeh-keş ve cenūben ba' $\dot{Z} 1$ 'Abdu'r-raḥmān Kelek ve Muhammed Cān Șüfì ve ba' $\dot{z} 1$ 'āmme yolı imdi bu yarlığ-1 hümāyūn-1 'āli mażmūniga muttali'

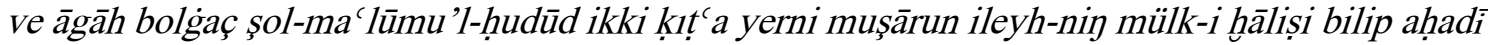
ve âferīde-i dāhhil ve muzāḥim bolmasun 'bir kısmı Nahş Murad Daruga, Hasan Tarakçı, Ata kulı Bileğici, Usta Avaz Niyaz, Baba Can, Abdurrahman Kelek, Baba Can Harat, Muhammed Can Sufi, kuzey olarak Aşur Muhammet, Baba, Yakup Bay, Rahmanberdi, adı zikredilen bazı daruga ve Abdurrahman Kelek, bir kısmı Zehkeş, batı olarak Zehkeş, güney olarak bir kısmı Abdurrahman Kelek ve Muhammed Can Sufi, bir kısmı amme yolu. Şimdi padişahın bu yüce fermanı(nın) mazmunun(d)a(n) haberdar vebilgi sahibi olduklarında hudutları malûm şu iki kıta yeri müşarünileyhin halis mülki bilip kimse ve hiçbir canlı müdahil olmasın ve zahmet etmesin"(HY-T38/9).

tarag̣çı: Kelimenin kökünün 'dağıtmak, ayırmak, vs.' anlamlarına gelen tar- (Clauson 1972: 529a) olduğu bu fiile önce fiilden ad türetme eki -gAk'1n (Clauson 1972: 539b; Erdal 1991: 391) getirilmesiyle tarġak kelimesinin, daha sonra da adlardan ad türetme eki +çI'nın söz konusu ad gövdesine getirilmesiyle bu meslek adının türetildiği anlaşılmaktadır. Eski Uygur Türkçesi dönemi metinlerinden itibaren tarihî ve modern Türk yazı dillerinin tamamında şu şekilde tanıklanmaktadır: Eski Türklerde tarakçılık mesleği için kullanılan targakçı sözü Eski Uygurca sonrasında, İbni-Mühennâ Lûgâti'nde tarakçı "tarak yapan” (Battal 1997: 68), Kupçak Türkçesinde tarakşı "tarakçı." (Toparlı vd. 2003: 263), Osmanlı Türkçesinde tarakcı "tarayıcı." (TDK 1996: 3761) olarak karşımıza çıkar. Targakçı günümüzde Türkiye Türkçesinde tarakçı "1. Tarak yapan veya satan kimse. 2. Taraklama işi yapan kimse." (TDK 2005: 1905); Gagavuz Türkçesinde tarakçı "Tarakçı." (Gaydarci 1991: 238), Azerbaycan Türkçesinde daragçı "1. Tarak yapan usta. 2. Maddî menfaat karşılığı yün tarayan kimse.” (Altaylı 1994: 232), Özbek Türkçesinde tarokçi "Tarak yapan usta." (Marufov 1981a: 128) biçimlerinde yaşamaktadır.

ba'żı Nahşs-Murād daruġa ve Hasan Tarağçı ve Ata ḳulı Kayrakçı ve Usta 'A vaż Niyāz ve Baba Cān ve'Abdu'r-rahmān Kelek ve Baba Cān Harāțe Muhammed Cān Șūfì ve şimālen 'Asșūr Muhammed ve Baba ve Ya'kūub Bay ve Raḥmān-birdi ve ba'żı mezkūr daruğa ve 'Abdu'rraḥmān Kelek ve ba' ̇̇-s1 Zeh-keş ve garben Zeh-keş ve cenūben ba' $\dot{z} 1$ 'Abdu'r-raḥmān Kelek ve

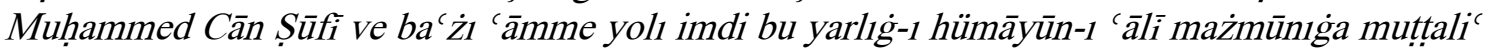

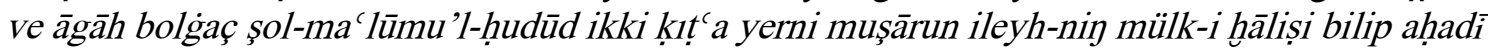
ve āferīde-i dāhil ve muzāḥim bolmasun 'bir kısmı Nahș Murad Daruga, Hasan Tarakçı, Ata kulı Bileğici, Usta Avaz Niyaz, Baba Can, Abdurrahman Kelek, Baba Can Harat, Muhammed Can Sufi, kuzey olarak Aşur Muhammet, Baba, Yakup Bay, Rahmanberdi, bir kısmı adı zikredilen daruga ve Abdurrahman Kelek, bir kısmı Zehkeş, batı olarak Zehkeş, güney olarak bir kısmı Abdurrahman Kelek ve Muhammed Can Sufi, bir kısmı amme yolu. Şimdi padişahın bu yüce fermanı(nın) mazmunun(d)a(n) haberdar vebilgi sahibi olunca hudutları malûm şu iki kıta yeri müşarünileyhin halis mülki bilip kimse ve hiçbir canlı müdahil olmasın ve zahmet etmesin"(HYT38/9). 


\subsection{Maliye ile İlgili Meslek ve Unvan Adları}

'ameldār: Arapça 'amel kelimesine Farsça, addan ad türetme eki+dār' 'n getirilmesinden teşekkül etmiş bir kelimedir. Terim olarak devlet adına vergi toplamakla görevli memurlar olup toplanacak verginin miktarı, taksimi ve tahsili için halife, hükümdar veya emir tarafından emvalin alınması işine memur edilen vergi tahsildarı, mütesellim, mütevelli, vali gibi kimselerin unvanıdır. Âmil kelimesinin müradifi olan 'ameldār kelimesi, X. yüzyıl sonlarında Gaznelilerde, onlardan sonra Hindistan Türk devletlerinde Altınordu Hanlığında, Timürlülerde yaygın olarak kullanılmıştır (Köprülü 1983: 110-111). Karahıtay ve Harezmşahların baskak diye adlandırdıkları bu idare ve maliye memurları, İlhanlı ülkesinin değişik bölgelerinden Anadolu'ya getirilmiştir (Togan 1981: 238). Çalışmamızda yazının muhatabı olan kimse ile meslek gruplarının adlarının sıralandığı inscriptio ile tehdit ve tekîdin bulunduğu sanctio bölümünde tarhanlık ve muafiyet tanınan kimseler üzerinden vergi kalemlerini kaldırıp hiçbir vergi talep etmemelerinin emredildiği vergi memurları arasında adı geçen bir memuriyettir.

merfü'u'l-kalem ḳlduḳ ehl-i kalem kalemlerini ve 'ameldārlar kademlerini tarta tutsunlar ikin ikseler cerīb ve tanābāne tilemesünler yipekidin māl almasunlar '(vergi) kalemlerini kaldırdık. Kalem ehli (mutasarrıflar onlar üzerinden vergi) kalemlerini kaldırsınlar, ameldârlar (onların arazilerinden) ayaklarını çeksinler. Ekin ekseler cerîb ve tanâbâne (vergisi) dilemesinler. İpeğinden mâl (vergisi) almasınlar" (HY-T4/9).

bāc-bān: Geçiş vergisi tahsildarları, bāc vergisini isteyen gümrükçü anlamına gelen Farsça, türemiş bir kelimedir. Şehir pazarlarında tahsil edilen resimler veya ticaret mallarından alınan vergileri ifade etmede kullanılan $b \bar{a} c$ vergisini toplayan memurlar için Türk-İslâm devletlerinde $b \bar{a} c-h h^{\swarrow a} h$, bāc-dār (Köprülü 1983: 167) gibi kelimeler kullanılırken Türkistan hanlarına ait belgelerde $b \bar{a} c-b \bar{a} n$ kelimesinin kullanıldığı görülmektedir.

karavul ve toksavul-lar ve bāc-bān ve harc-bān-lar dāhil ve muzāhim bolmasunlar "karavul, toksavul, bâcdâr ve harcdârlar müdâheledebulunup zahmete sokmasınlar" (HY-T67/28).

çihil-yekçi: <çihil(F.)+yek(F.)+çi (T.). Gelirin kırkta biri değerinde alınan bir tür vergi olup bu vergiyi tahsil eden görevlilere ise çihilyekçi adı verildiği belgelerden anlaşılmaktadır. Türkistan hanlıklarına ait belgelerde bu verginin ticaret için bir yerden başka bir yere giden kimselerden her yerge sūdā içün barsa ve kilse biy ve karavul ve çihilyekçi ve darvāzabān ve kütvel bāc ve tamga tip bir habbe ve bir dinār almasunlar... 'her nereye ticaret için gitse ve gelse biy,karavul, kırkta birci, kale kapısı muhafizı ve kütvel (ondan) bāc ve tamġa (vergisi) diye/bahanesiyle bir habbe (mâl) ve(ya) bir dinar (para) almasınlar" (HiY-T5/10) alınan bir tür vergi olduğu anlaşılmaktadır.

her yerge sūdā ücün barsa ve kilse biy ve karavul ve çihil-yekçi ve dervāze-bān ve kütvel bāc ve tamġa tip bir habbe ve bir dīnār almasunlar ... "her nereye ticaret için gitse ve gelse bey, karavul, kırkta bir vergi memuru, kale kapısı muhafızı, kütvel bâc ve tamga diye/bahanesiyle bir habbe (mâl) ve(ya) bir dinar (para) almasınlar" (HY-T6/10).

harc-bān: 'vergi, sarf, gider' (Devellioğlu 1990: 392) anlamındaki, Arapça harc kelimesine, adlardan meslek adları türetmeye yarayan, Farsça $+b a \bar{n}$ (Devellioğlu 1990: 86) ekinin getirilmesinden teşekkül etmiş bir kelime olup harc vergisini tahsil eden vergi memurları için kullanılır. Türkistan sahası yarlıklarında harc $\sim$ harāc $\sim$ harāāāt terimlerinin, kazan harcı, māl-ı deh$d \bar{u}$ harc "vergi, pazar resmi, baş vergisi, seyahat eden devlet yetkililerine yemek sağlama vergisi; onda bir mâl vergisi" örneklerinde görüldüğü gibi çeşitli türlerinin olduğu tespit edilmiştir. Bununla birlikte incelemeye esas alınan yarlıklarda söz konusu verginin genellikle pazar ve (transit) yollardaki tüccarlardan alınan bir çeşit gümrük vergisi olan bāc ile birlikte anıldığ

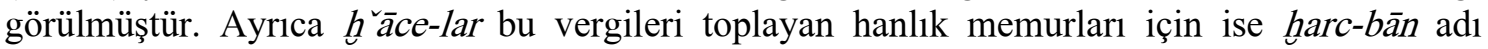
verildiği tespit edilmiştir.

karavul ve toḳsavul-lar ve bāc-bān ve harc-bān-lar dāhil ve muzāhim bolmasunlar "karavul, yol muhafızı, bâcdâr ve haracdârlar müdaheledebulunmasınlar ve zahmet etmesinler" (HY-T67/28). 
hazīneçi: 'Hazine, kıymetli mücevheratın saklandığı yer, hazinedarlık' anlamlarına gelen, Arapça hazine kelimesine, mansıp, hüner ve meslek adları türetmeye yarayan Türkçe + çi ekinin getirilmesiyle teşekkül etmiş bir meslek adıdır (Barutçu Özönder 2011: 34). Türkistan hanlığ topraklarında devlet hazinesine aktarılması gereken vergileri toplamakla görevli memurlar için kullanılan bir terim olduğu anlaşılmaktadır. Uygur Kağanlığında toplanan vergileri teslim eden ya da halktan vergileri doğrudan toplayan devlet haznedarı anlamındaki agıçı (Caferoğlu 1934: 21), Osmanlı ve Timürlülerdeki hazinedâr (Yağlı 2014: 108), Kırım ve Kazan hanlıkları yarlıklarındaki hazîr (Özyetgin 1996: 215) kelimelerine tekabül etmektedir. Hazineçi, Türkistan sahasına ait incelenen bir belgede hanın askerî, hukukî ve ticarî açıdan pek çok imtiyaz ile vergilerden muafiyet tanıdığı belge sahibine sıkıntı çıkarılmaması emredilen bir meslektir.

hazineçi ve tahkikk-çi ve tünkatar ve barsbān tigmesünler. 'Hazîneci, tahkîkçi, tünkatar ve parsçı dokunmasinlar"(Bregel 2007:3/19).

mülāzım: Türkistan hanlıkları arazilerinde vergi teftişleri ve tahsili için gönderilen memurları ifade etmek için kullanılan bir terimdir. İlhanlılar döneminde Gazan Han, 703 (1304) yılında bazı eyaletlerde valilerin keyfî uygulamalarına imkân veren harz ve mukâseme metotlarını ilga etmiş, her vilâyet için kendi topraklarına ait defterlerin birer sûretini çıkarttırarak ilgili mülâzımların zimmetine vermiş, böylece tahrifatın önüne geçmeye çalışmıştır. Neticede mükellefler haracın takdiri, kesinleştirilip kayitlara geçirilmesi, peşin tahsil edilmesi, aynî verginin nakde çevrilmesi işlemlerinde her türlü ek ödemeden, memurların zulmünden ve harcırahlarının karşılanmasından kurtulmuşlardır. Daha önce vilâyetlere vergi teftişleri için gönderilen adliye memurlarının yerine başmüfettiş sıfatı ve "mülâzım-1 dîvân-1 büzürg" unvanıyla dâimî görev yapacak uluğ bitikçiler tayin edilmiştir.

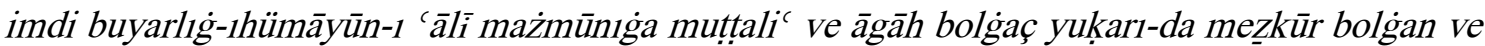

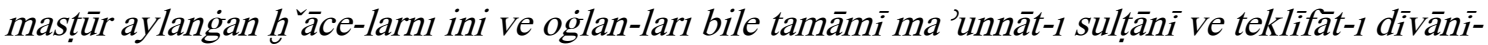
dın soy ve müsteșnā bilip ehl-i kalem kalem-lerin ve barça 'amel-dārlar kadem-lerin tarta tutsunlar bïgār ve haş̧ar kazu ve kaçu atlanu ve tüşübirü ve alu buyurmasun-larilçi ve yolçı barğuçı ve kilgüçi üyleriga tüşüp konalga ve süysün gele ve karaları-dın ulag tilemesünler ve baş pulı ve kazan harcı ve tamġa ücre-si ve mīr-āb vekütevül alımı ve karavulve taskavul ve bars-bān sıyı dip bir habbe ve dāne tama' kılmasunlar ve iş ve küç üstige yürüyturgan mülāzım-lar kömek pulı ve munlarga ohşsaş belā ve bid'at-dın tarhan ve merfü' $u$ 'l-ḳalem bilip żarar ve zaḥmet yitkürmesünler "şimdi bu yüce yarlığın muhtevasın(d)a(n) haberdar ve bilgili olduklarında yukarıda (adları) yazılı hâceleri, küçük kardeş ve abileri ile sultanlığın her tür maunnatı ve divan vergilerinden muaf ve müstesna bilip kalem ehli (mutasarrıflar onlar üzerinden vergi) kalemlerini kaldırsınlar, bütün vergi tahsildârları (da onların arazilerinden) ayaklarını çeksinler. Bîgâr, haşar, kazu, kaçu, atlanu ve tüşü (vergisi ve yükümlülüğü), birü ve alu (vergisi) buyurmasınlar. Elçi, yolcu, giden ve gelen evlerine (zorla) konuk olup konalga ve süysün (vergisi), sürü ve hayvanlarından ulag (hayvan1) istemesinler. Başpulu, kazan harcı tamga ücreti, su emiri hakkı, kütvel hakkı, karavul hakk1, yol muhafızı hakkı ve parsçı hakkı diye bir habbe (mal) ve bir dinar (para) beklemesinler. İş ve küç (hizmet yükümlülüğü) üzerinde duran mülazımlar kömek pulu ve bunlara benzer bela ve bid'attan tarhan olduğunu ve (üzerinden) vergi kalemi kaldırılmış kimselerden bilip zarar ve zahmete uğratmasınlar" (HY-T27/26).

müşrif: 'Yükseğe çıkmak, yüksekten bakmak; kontrol etmek' (Kanar 2009: 1632) anlamlarındaki işrâf masdarının ism-i fâili olan müşrif; hanlığın askerî ve adlî teşkilatları dışında her türlü malî işlerini ve hesaplarını kontrol eden memur. Türk-İslâm devletlerinde idarî ve malî konularda denetleme ve teftiş yetkisine sahip divan-1 işrâf adı verilen bir daire mevcuttu. İşte bu dairede görevli memurlar olan müşrifler; devletin maliyesinden sorumlu, memleketteki gelir ve giderleri kayıt altına alan, bu kayıtların tutulduğu maliye defterlerini düzelten kimselerdir (Turan 2002: 160). Kendisinden önceki dönemlerde olduğu gibi, Türkistan hanlıkları döneminde demalî ve idari işleri kontrol ettikleri, icap eden yerlere memurlar gönderdikleri, hanlığa ait bina vemasrafları kayıt altına aldıkları söylenebilir. 
dìvān ve terāzūbān ve dīvān bigi ve mìr-i tümen ve mīr-āb ve müssrif ve dervāzebān ve şığavul ve kütvel ve korugimāl barça 'ummāl ve duhhāl dahl ḳlmasun-lar "divan, tartı memuru, divan beyi, tümen emiri, su emiri, kale kapısı muhafızı, saray teşrifatçısı, kütvel, korukçu, tüm âmil ile dâhiller müdahale etmesinler" (HY-T2/19).

terāzū-bān: 'Tartı, terazi'anlamlarına gelen, Farsça terāzū kelimesi ile sonuna geldiği kelimelere 'koruyan, sahip' anlamları katan, Farsça-bānekinin getirilmesiyle teşekkül etmiş bir terimdir. Altınordu ve Kırım Hanlığı sahasındaki tartnakçı 'kantarcı, kantar memuru' (Özyetgin 1996: 236) terimine karş1lık geldiği söylenebilir. Bal, ipek, kumaş, çeşitli dokumalar, pamuk, arpa, buğday, pirinç yani tahıl, un, yağ gibi malların ölçüm ve tartımında hile yapılmasını önlemek için kadı nâibinin nezaretinde esnaf temsilcilerinin de hazır bulunmasıyla terāzū-bāntarafindan tartılıp daha sonra da ağırlık, kalite ve çeşidine göre narh ve vergiye tâbi tutulurdu.

bāc-bān ve keştī-bān ve ḳoruğ-bān ve dervāze-bān ve terāzū-bān biy karavul kütevül bir ḥabbe ve bir dīnār tama' ve tevakku' kılmasunlar hīç vechdin żarar ve zaḥmet yitkürüp āzūrde-huâtır kılmasunlar ve her yılda tāze nişānn tilemesünler 'bâcdâr, gemici, korukçu, kale kapısı muhafızı, tartı memuru, biy, karavul ve kütvel bir dinar (para) ve(ya) bir habbe (bir mal) beklemesin ve ummasınlar. Hiçbir şekilde zarar ve zahmete uğratıp hatırlarını kırmasınlar. Her yıl yeni bir nişan talep etmesinler" (HY-T14/15).

'ummāl: Geçici veya sürekli bir vazifenin ifâsı ile mükellef memur; belirli bir bölgede haraç, 'össr, himāye, ganimet gibi vergilerden birinin veya tamamının tahsili ile mükellef maliye memuru; büyük bir idarî sahanın yahut büyük şehrin umumî idaresine memur anlamındaki, Arapça 'āmil kelimesinin çoğulu. 'Ámil kelimesi, Farsçanın resmî veya edebî dil olarak kullanıldığı Doğu memleketlerinde, 'ameldār, kārdārr, kārdān, kārkünān gibi, yine aynı mânayı ifâde eden Farsça şekiller almıştır. Bu terimler 'āmil, yani vergi memurunun eş anlamlısı olarak bu memleketlerde eski zamanlardan beri kullanılmıştır (Köprülü 1983: 108-110). 'Ámillerin hizmetlerine karşılık olarak Akkoyunlular döneminde reayadan rüsūm-1 'ummāl (Kök 2020: 611), Safavîlerde hakkku's-sa'y-1 'ummāl (Kök 2020: 627) adı altında vergiler aldıkları tespit edilmiştir. Türkistan hanlıklarına ait tarhanlık ve soyurgal yarlıklarında belgenin muhatabı olan protokol üyeleri sayılırken ismi zikredilen meslek gruplarındandır.

dìvān ve terāzū-bān ve dīvān bigi ve mìr-i tümen ve mīr-āb ve müsrif ve dervāze-bān ve şiğavul ve kütvel ḳorugimāl barça 'ummāl ve duhhhāl dahl ḳ1lmasun-lar "divan, tartı memuru, divan beyi, tümen emiri, su emiri, kale kapısı muhafızı, saray teşrifatçısı, kütvel, korukçu, tüm âmil ile hana yakın beyler müdahale etmesinler" (HY-T2/19), bākị nevvāb u hüccāb ve sāyir-i mutesaddiyān-1

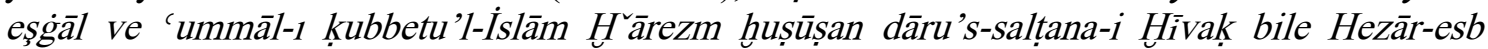

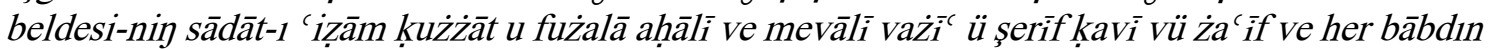
vukūflık ulug erbāb darug̉a ve kelāntān aḥsena'llāhu aḥvālihum-ġa ol-kim ... ‘'̇slâm'ın kubbesi olan Harezm'in bâkî nâipleri ve hâcipleri ile vesayir meslek girişimcileri, âmilleri özellikle saltanat yurdu Hive ile Hezaresb beldesinin ulu seyyitleri, kadıları, fazılları, ahali, efendileri sıradan veya soylu, güçlü ya da zayıf her hususta vakıf büyük erbap, daruga ve kelanterine -Allah, onların durmunu güzel k1lsın!- o ki ..."(HY-T21/7).

zek`ātçı: İslam devletlerinde yoksullara dağıtılmak üzere hâli vakti yerinde olanların mallarının kırkta birini ödemekle mükellef oldukları şerî vergi türüne zekât denmektedir. Zekât, her türlü sermayeden değil para, menkûl mallar ve ticaret mallarından alınmakta; nemâ kabiliyeti olmayan mallarla üretim için kullanılan sabit mallar bunun dışında tutulmaktaydı. Bu vergiyi toplamakla görevli memurlara ise zeǩātçı adı verilmektedir. Türkistan hanlıklarında zekât vergilerinin toplanması ve gereken yerlere harcanmasından sorumlu olan kimselere ise zekathanacı denmekteydi (Kar1ev 2016: 36).

garaż bu tahriìrdin ve müdde ‘ $\bar{a}$ ’ bu takrīrdin bu kim pādşāh-1 İslām-penāh bir kişi-ni zek ātçı veyā

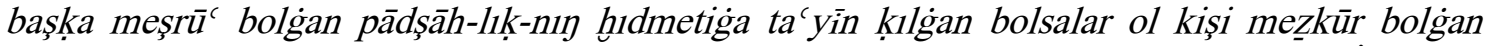
'amelde niçe vakt-lar bolup ... 'bu tahrirden garez ve bu takrirden iddia edilen budur ki İslâm'ın 
sığınağı olan padişah bir kişiyi zekâtçı veya meşrû olan başka (bir) hanlık hizmetine tayin etseler o kişi söz konusu vazifede ne kadar süre olup ...”(Bregel 2007: 29/2).

\subsection{Sulama İşleri ile İlgili Meslek ve Unvan Adları}

mïr-āb: 'emir, bey' anlamına gelen, Farsça mîr ile 'su' anlamındaki, bir başka Farsça kelime olan $\bar{a} b$ ' nn birleşmesiyle teşekkül etmiş bir kelimedir. Suların tanzimi işine bakan mīr-āb, hanlığın arazileri üzerindeki baraj ve kanalların inşası, bunların bakım ve onarımı ile su kuyularının muhafazasını sağlayan memurlar olup aynı zamanda bu kimselerin iaşesi için toplanan vergiler için de kullanılan bir terimdir. İran coğrafyasındaki varlıklarının Selçuklu öncesine dayandığı miräblar maiyetlerinde çalışan görevlilerle beraber ziraî üretimi artırmak için yeni sulama kanallarının açılması ve suların tanzimi işleriyle ilgilenmişlerdir. Söz konusu dönemde sayılarının 12.000'i bulduğu mirrāblar hem üretimin artmasını, hem de köy ve şehirlerin büyüyüp bayındır hâle getirerek ticarî hayatın gelişmesini sağlamışlardır (Özgüdenli 2019: 58-59). Türkistan hanlığ arazilerinde nehir ve irmaklarından temin edilen sularla büyük tarım arazileri oluşturulmakta, daha sonra bu arazilerde arpa, buğday, darı, pamuk, pirinç, sebze, meyve ve ipek yetiştirilmekteydi (Karıev 2016: 44). Eski Türkçe döneminde suvçı ile karşılanan mirr-āà'ın modern Türk yazı dillerindeki karşılıkları şöyledir: Azerbaycan Türkçesinde suçu "1. Su taşıyan kimse. 2. Ekin, tarla, bağ vs. sulayan kimse.” (Altaylı 1994: 1063); Kırgız Türkçesinde suuçu "1.Sulayıc1 2.Sulama işleriyle uğraşan" (Yudahin 1998: 670); Kazak Türkçesinde suş1 "1.Su taşıyıcısı, saka. 2.Sulama işi yapan, sucu." (Koç vd. 2003: 492); Özbek Türkçesinde suvçi "1.Ekinleri, fideleri sulamakla görevli köylü, sulama uzman1. 2.Saka. 3. Su satıcısı. 4.Suda boğulanları kurtarmakla görevli kimse." (Marufov 1981: 81), Türkmen Türkçesinde suvç1 "Sucu, su getiren, su taşıyan, su satan, su veren." (Tekinvd. 1995:591), Yeni Uygur Türkçesinde suçi 'Sucu.'(Necip 1995: 364). ${ }^{22}$

imdi bu yarliğ-1 'ālì mażmūniga muțtali' ve āgāh bolġaç yukarı-da mežkūr bolg̀an ve masțūr

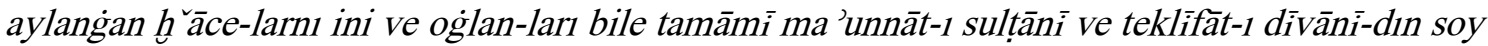
ve müstesnā bilip ehl-i kalem ḳalem-lerin ve barça 'amel-dārlar ḳadem-lerin tarta tutsunlar bīgār ve haş̧ar kazu ve kaçu atlanu ve tüşü birü ve alu buyurmasunlar ilçi ve yolçı barğuçı ve kilgüçi üyleriga tüsüp konalga ve süysün gele ve karaları-dın ulag tilemesünler ve baş pulı ve kazan harc1 ve tamga ücre-si ve mīr-āb ve kütevül alımı ve karavul ve taskavul ve bars-bān siyı dip bir habbe ve dāne tama'kılmasunlar "şimdi bu yüce yarlığın muhtevasın(d)a(n) haberdar ve bilgili olduklarında yukarıda (adları) yazılı yüz bir hâceyi, oğulları ile beraber alğut, salg̀ut, biggār, haşar, kazu ve kaçu (vergisi) ile bunlara benzer sultanlık maunlarıyla divanla ilgili yükümlülüklerden tarhan olduklarını ve (üzerlerinden her tür vergi) kalemlerinin kaldırılmış (kimselerden) olduğunu bilip kalem ehli (mutasarrıflar onlar üzerinden vergi) kalemlerini (kaldırsınlar), bütün vergi tahsildârları (da) ayaklarını (onların arazilerinden) çeksinler.". Bîgâr, haşar, kazu, kaçu, atlanu ve tüşü (vergisi ve yükümlülügü̈), birü ve alu (vergisi) buyurmasınlar. Elçi, yolcu, giden ve gelen evlerine (zorla) konuk olup konalga ve süysün (vergisi), sürü ve hayvanlarından ulag(hayvanı) istemesinler. Başpulu, kazan harcı tamga ücreti, su emiri hakkı, kütvel hakkı, karavul hakkı, yol muhafızı hakkı ve parsçı hakkı diye bir habbe (mal) ve bir dinar (para) beklemesinler"'(HYT27/026).

\subsection{Ticaret ile İlgili Meslek ve Unvan Adları}

sūdāgerān: 'Tüccar, bezirgân' anlarına gelen, Farsça birleşik yapılı bir isimdir (Devellioğlu 1990: 1151). Türkistan hanlıklarının önemli gelir kaynaklarından birini de ticaret oluşturmaktaydı. Hanlıkların, Afganistan, Hindistan, Çin, İran, Rusya ile olan ticaretlerinde çay, şeker, Kaşmir halısı, çiniden yapılmış eşyalar, porselen eşyalar, ipekli kumaşlar, bez, çelik, demir eşyalar, bal, ayna, pirinç, tütün, pamuk, yün, deri, ipek, ipek kozası, kömür, pirinç, kuruyemiş ve çeşitli meyveler başta gelmekteydi. Ayrıca dokumacılık, dericilik, çömlekçilik, terzilik, boyacılık,

\footnotetext{
${ }^{22}$ Detaylı bilgi için bk. (Şen, 2007: 70-71).
} 
bakırcılık, demircilik, marangozluk fazla gelişmiştir ve bunların da ticareti yapılmıştır (Zâde 1968: 21).

olțarafdın ve yā özge țarafdın kilgen ilçi veyā sūdāgar bolsa alar-nın mālların zor ve zulm birle

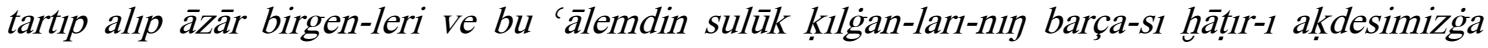
ma' lüm boldı "o taraftan veya başka taraftan gelen elçi veya tüccar olsa onların mallarını zor ve zulüm yoluyla çekip (ellerinden) alıp azarlayanları, bu âlemden onlara katılanların tamamı mübarek (hanlık) hatırımıza malûm oldu" (HBR-T1/18).

\subsection{Ulaşım ile İlgili Meslek ve Unvan Adları}

keştī-bān: Büyük göl ve nehirlere yakın bölgelerde yerleşmiş olan Türkistan hanlıklarında, suyla ilgili mesleklerden biridir. Fatih Sultan Mehmet'in, Akkoyunlu Uzun Hasan Bey'i mağlup ettikten sonra kaleme alınan fetihnâmenin on beşinci satırındaki kemeçi-ler-ge 'gemicilere' kelimesine tekâbul etmektedir (Arat 1939: 185-236). Ulaşım bakımından ırmak ve göllerden de yararlanıldığı Türkistan hanlıklarında tüccarlar, mallarını ticarî gemiler ve kayıklar ile bir kıyıdan başka bir kıyıya ulaştırıyorlardı. Bu gemi ve kayıkları yöneten kişilere Türkistan hanlıklarında keşti-bān veya kime darugaları (HY-T54/23) dendiği anlaşılmaktadır.

bars-bān ve keştī-bān ve ḳoruġmāl ve dervāze-bān bir habbe ve bir dīnār țama ḳ1lmasunlar ḳażu ve kaçu bīgār ve haşar buyurmasunlar her țarafge sūdā üçün barsa-lar ve kilse-ler bāe ve tamg̀a ve çihil-yek ve rāh-dārlık ve hazine-ç-lık tip hịç nimerse tama' ḳılmasunlar ve hïç vech-din żarar ve zahmet yitkürmesünler 'parsçı, gemici, korukçu ve kale kapısı muhafızı bir habbe (mal) ve bir dinar (para) beklemesinler. Kazu, kaçu, bîgâr ve haşar (vergisi ve yükümlülüğü) buyurmasınlar. Her nereye gitseler ve gelseler bâc, tamga, kırkta bir, rahdarlık, hazinecilik (vergisi) diye hiçbir şey ummasınlar. Hiçbir şekilde zarar ve zahmete sokmasınlar" (HY-T8/13), husșūsan Konrat

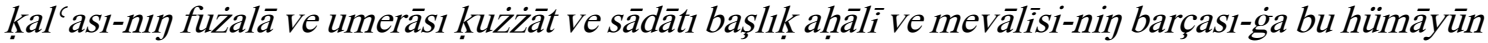

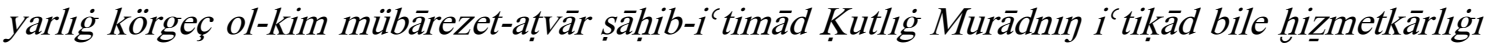
dergāh-1 gerdūn-iştibāhımız āstāne-si-nin mülāzım-larıġa kabūl ḥüsni tapǵanı üçün 'ināyetimiz

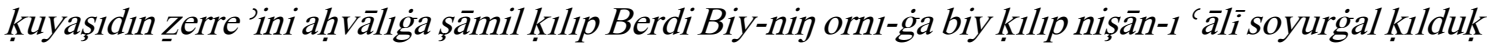
'Özellikle Konrat Kalesi'nin fazılları, emirleri, kadıları, seyyitleri, toplum önderleri ile bütün efendilerine bu padişah yarlıg(nn) görünce/gösterdiklerinde o ki savaşçı karakterli, itimat sahibi Kutlu Murad'ın itikât ile hizmet ettiği dönen feleği andıran dergâhımız eşiğinin mülâzımlarına güzel kabul görmesi için inayetimiz güneşinden (bir) zerreyi ahvâlini kapsayacak biçimde (düzenleyip) Berdi Bey’in yerine bey kılıp (bu hususta) yüce nişanla soyurgal kıldık" (HYT18/4).

\subsection{Dinî Meslek ve Unvan Adı}

seyyid: Hz. Muhammed'in torunu Hz. Hüseyin'in soyundan gelenlere seyyid denir. Türkistan hanlıklarındaki ruhanîler arasında en saygın kimselerdi. Büyük nüfuz sahibi olan bu zümre idarecilerle halktan büyük itibar görmüşlerdir. Seyyitler, hanlıkta hükümdarlar tahta çıktıklarında hükümdarlık alâmeti olan hutbenin okunması, elçilik vazifesiyle hanı temsil etme gibi önemli görevleri ifa ederlerdi. Belgelerde 'alī-nihād, 'izāàm, kirām, sādāt-1 dūdmān-1 muștafāvī eşrāf-ı hānedān-1 Murtażavī 'umdetü'l-'ulemā vezübdetü'l-umerā-y1 siyādet-penāh necābet-destgāh sıfatlarıyla birlikte verilen bu kişiler için h̆̌āee, seyyid ve şeyh gibi unvanlar kullanıldığı tespit edilmiştir.

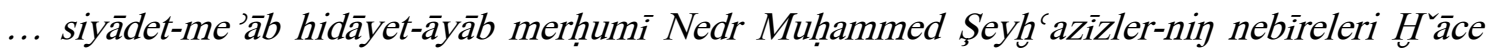

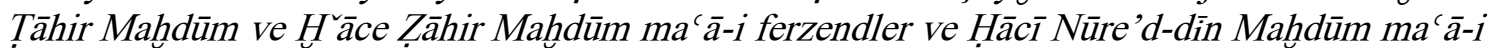
birāderler ve ferzendler ve Seyyid Manșūr Mahdūmma' $\bar{a}-i$ birāder ve ferzendler ve 'Ísmetullāh Mahdūm ma'ā-i birāder ve ferzendler ve Hudāy-dād Mahdūm hasbü'ş-şer'-i şerīf bular-nin

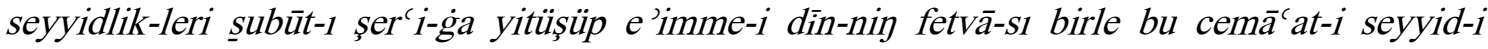

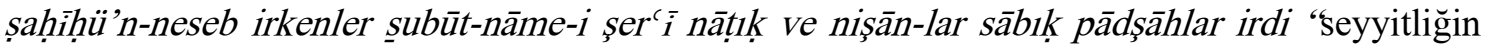
sığınağı, hidayetin iyâbı merhum Nedr Muhammed Şeyh azizlerin torunları Hace Tahir Mahdum ile Hace Zahir Mahdum ile birlikte oğulları, Hacı Nureddin Mahdum ile birlikte biraderleri ve 
oğulları, Seyyid Mansur Mahdum ile birlikte biraderi ve oğulları, İsmetullah Mahdum ile birlikte biraderi ve oğulları ve Hudadâd Mahdum İslâm şeriatına göre bunların seyyitlikleri şerî sübutlara erişip dinî liderlerin fetvasıyla bu cemaati nesep olarak gerçek(ten) seyyit oldukları(nı gösteren) şerî belgeler ile mazideki padişahların nişanlı (belgeleri) idi”(HY-T9/7).

\section{Sonuç}

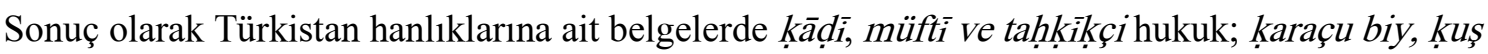
bigi, kütvel, mìr-i tümen, nöker, serdār ve yüz başı/bigi askerlik; daruga, dervāzebān, karavul, koruġbān/korugimāl, şığavul, tokssavul, tünkatar iç güvenlik; bars-bān ve kuş̧̧̧ı avc1lık; ākāa, atalık,

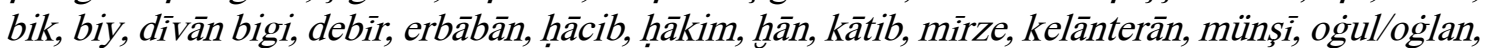
șadr, șāhib-dahl, töre, vezīr, bahādur ve h̆ hāce bürokrasi ve yöneticilik; barğuçı ve kilgüçi, ilçi, tavacı ve yolçı diplomasi; kayrakçı ve tarağçı esnaf ve zanaatkârlık; 'ameldār, bāc-bān, çihilyekçi, harc-bān, hazinneçi, mülāzım, müssrif, terāzūbān, 'ummāl ve zekātçı maliye; mīr-āb sulama işleriyle ilgili; sūdāgerān ticaret; keştībān ulaşım; seyyid din ile ilgili meslek ve unvanlar olarak karşımıza çıkmaktadır. Ayrıca döneme ait incelenen belgelerde dikkat çekici hususların başında yarlığın muhatabın adının değil de, unvanının yazılması gelmektedir. Buradan yapılması emredilen işin muhatabının şahıslar değil de makamlar olduğu anlaşılmaktadır. Böylece muhatap, muhtelif nedenlerden ötürü değişse de makam aynı kaldığı için emrin, mutlaka yerine getirilmiş olacağı anlaşılmaktadır. Yine meslek adlarına bakıldığında Çin, Hindistan, İran, Rusya gibi ülkelere olan transit ticaretle bu ticarette kervanların güvenliğini sağlamak için önlem alan görevlilere ait meslek adlarının önemli bir yer tuttuğu anlaşılmaktadır.

Söz konusu meslek isimleri kökenleri bakımından incelendiğinde ise bu isimlerin 2'sinin Türkçe,3'ünün Türkçe birleşik ad, 9'unun Türkçe+Türkçe, 1'inin Türkçe+Farsça, 1'inin Türkçe+Moğolca, 3'ünün Arapça+Türkçe, 10'unun Arapça, 2'sinin Arapça+Farsça, 4'ünün Farsça, 10'unun Farsça+Farsça, 2'sinin Farsça+Türkçe, 2'sinin Moğolca, yine ikisinin Moğolca+Moğolca yapısında olduğu görülmüştür. Bu durum, Arapça, Farsça ve Moğolcanın Türkistan hanlıklarının sosyal ve kültürel hayatı üzerindeki etkisini açıkça göstermesi açısından önemlidir. Yine tarhanlık belgelerindeki meslek adlarında adlardan yeni adlar türetmede $+\mathrm{cI}$ ekiyle kurulmuş olanların sayısal çoğunluğu gözlerden kaçmamaktadır. + cI ekinin yabancı kökenli kelimelere Türkçe karşılıklar bulunmasında da etkin rol oynadığı görülmektedir. Kelimelerin sonuna gelerek "bakan, kollayan, gözeten" anlamında Farsça baniden fiilinden türemiş bir sıfat ile ilgili Türk diline geçmiş, bācbān, bārsbān, dervāzebān, keştīiān, ḳoruğbān örnekleri tespit edilmiştir.

\section{Kaynakça}

ABUŞKA SÖZLÜĞÜ (ABUŞ) (1972). (Yayına Haz.: Besim Atalay). Ankara: Türk Dil Kurumu Yayınları.

ALTAYLI, Seyfettin. (1994). Azerbaycan Türkçesi Sözlüğü I-II. İstanbul: MEB Yayınları.

ARAT, Reşid Rahmeti. (1939). “Fatih Sultan Mehmed'in Yarlığı”. Türkiyat Mecmuası, C. VI.

s. 286-322.

ARAT, Reşid Rahmeti. (1987). Gazi Zahirüddin Muhammed Babur Vekayi Babur'un Hâtıratı. C. II, Ankara: Türk Tarih Kurumu Yayınları.

ARAT, Reşit Rahmeti. (1979). Kutadgu Bilig III (İndeks). (Yayına Haz.: Kemal Eraslan, Osman F. Sertkaya, Nuri Yüce). İstanbul: Türk Kültürünü Araştırma Enstitüsü Yayınları.

ASQAROVA, Jannatkhon. (2015). Türkistan Hanlıkları Yazışmalarının Dil ve Üslup İncelemesi. Yayımlanmamış Yüksek Lisans Tezi. Ankara Üniversitesi Sosyal Bilimler Enstitüsü.

ATA, Aysu. (1997). Rabguzi Kısasü'l-Enbiya II-Dizin. Ankara: Türk Dil Kurumu Yayınları. 
ATA, Aysu. (2008). Prof. Dr. Saadet Çağatay'ın Tüm Makaleleri-I. İstanbul: Tahir Türkistan İdil-Ural Vakfi.

ATASOY, Okan Faysal. (2017). Kırım Yurtına ve Ol Taraflarga Dair Bolgan Yarlıklar ve Hatlar I-II. Ankara: Türk Dil Kurumu Yayınları.

AZERBAYCAN DILIININ IZAHLI LÜĞETİ IV (ADÍL). (2006). Baq1: Şerq-Qerb.

BÂBÜR, Gazi Zahir ed-din Muhammed. (2006). Baburnâme. (Çev.: Reşit Rahmeti Arat). İstanbul.

BARUTÇU ÖZÖNDER, Fatma Sema. (2011), 'Ali Şir Nevâyi: Muḥākimetü 'l-Luġateyn İki Dilin Muhakemesi. Ankara: Türk Dil Kurumu Yayınları.

BATTAL, Abdullah. (1997). İbni-Mühennâ Lûgati. Ankara: Türk Dil Kurumu Yayınları.

BAYRAKTAR, Nesri. (2004). Türkçede Fiilimsiler. Ankara: Türk Dil Kurumu Yayınları.

BREGEL, Y. (2007). Documents from the khanate of Khiva (17th-19th centuries). Bloomington, Indiana: Indiana University Denis Sinor Institute for Inner Asian Studies.

CAFEROĞLU, Ahmet. (1934). "Uygurlarda Hukuk ve Maliye Istılahları”. Türkiyat Mecmuası, C. IV. s. 1-43.

CLAUSON, Gerard. (1972). An Etymological Dictionary of Pre-Thirteenth Century Turkish. London: Oxford University Press.

CLEAVES, Francis W. (1953). "Daruga and Gerege". Harvard Journal of Asiatic Studies. Cambridge, No: XVI, s.237-259.

COURTEILLE, Pavet de (1870). Dictionnaire turc-oriental. Destine principalement a facilite la lecture des ouvrages de Bâbur, d'Aboul-Gâzi et de Mir-Ali-Chir Nevâi (DTO), Paris.

COURTEILLE, Pavet de. (1870). Dictionnaire turc-oriental. Destine principalement a facilite la lecture des ouvrages de Bâbur, d'Aboul-Gâzi et de Mir-Ali-Chir Nevâi. Paris.

DEVELLİĞGLU, Ferit. (1990). Osmanlıca-Türkçe Ansiklopedik Lügat. Ankara: Aydın Kitabevi.

ERASLAN, Kemal. (1980). Eski Türkçede İsim-Fiiller. İstanbul: İstanbul Üniversitesi Edebiyat Fakültesi Yayınları.

ERDAL, Marcel. (1991). Old Turkic Word Formation: A Functional Approach to the Lexicon. III. Wiesbaden: Otto Harrassowitz.

ERŞAHIN, Seyfettin. (2002). "Türk Hakimiyet Tecrübesine XV. Yüzyıldan Bir Örnek: Akkoyunlu Hakimiyet Anlayıșı ve Yönetim Yapısı". Türkler Ansiklopedisi. C. 7, Ankara: Yeni Türkiye Yayınları.

GAYDARCi, G. A. ve diğerleri. (1991). Gagauz Türkçesinin Sözlüğü. (Çev.: Abdülmecit Doğru ve İsmail Kaynak). Ankara: Kültür Bakanlığı Yayınları.

GÖKSU, Erkan. (2010). Türkiye Selçuklularında Ordu. Ankara: Türk Tarih Kurumu Yayınları.

GÜZELDİR, Muharrem. (2002), Abuşka Lügati (Giriş-Metin-İndeks). Yayınlanmamış Doktora Tezi. Atatürk Üniversitesi Sosyal Bilimler Enstitüsü.

HASANZÂDE, İ. (2001). Hükümet-i Türkemanan-ı Karakoyunlu ve Akkoyunluder İran. Tahran: Semt.

HORST, Heribert. (1956). Die Staatverwaltung der Grosseğuqen und Iran unter den Horezmšhâhs (1038-1231). Wiesbaden.

ISLAM ANSIKKLOPEDISII. (2002). C. 25, s. 203. 
KAÇALİN, Mustafa Sinan. (2011). Niyâzî Nevâyî'nin Sözleri ve Çağatayca Tanıklar, ElLugatu'n-Neva'iyye ve'l-İstişhadatu'l-Cagata'iyye. Ankara: Türk Dil Kurumu Yayınları.

KANAR, Mehmet. (2009). Osmanlı Türkçesi Sözlüğü. İstanbul: Say Yayınları.

KARIEV, Alıtmamat. (2016). Orta Asya'da İslâm Yargı Teşkilâtı Ve İşleyişi (1709-1876 Hokand Hanlı̆̆ı Ve 1865-1928 Rus İşgali Süreci Örneği). Yayınlanmamış Doktora Tezi. Marmara Üniversitesi Sosyal Bilimler Enstitüsü.

KOÇ, Kenan ve diğerleri. (2003). Kazak Türkçesi-Türkiye Türkçesi Sözlüğü. Ankara: Akçağ Yayınları.

KÖK, Abdullah. (2019). Türklerin Entelektüel Mirası Kutadgu Bilig Devlet: Adalet, Kut, Töre. İstanbul: Kesit Yayınları.

KÖK, Ali. (2017). “İran ve Azerbaycan'da Kurulan Türk-Moğol Devletlerine Ait Belgelerde Geçen Moğolca Unsurlar”. Uluslararası Türk Dünyası Stratejik Araştırmalar Kongresi Bildiri Kitabı. s. 22-31, Antalya.

KÖK, Ali. (2020). Selçuklu Sonrası Anadolu, Iran, Irak ve Kafkasya Sahası Türk Devletlerinde Yazışma Kültürünün Dil ve Üslûp Yönünden İncelenmesi, Savunmaya Hazır Doktora Tezi, Ankara Üniversitesi Sosyal Bilimler Enstitüsü.

KÖPRÜLÜ, Mehmet Fuad. (1983). İslâm ve Türk Hukuk Tarihi Araştırmaları ve Vakıf Müessesesi. İstanbul: Ötüken Neşriyat.

KUCUR, Sadi S. (1994). “Debîr”, İslam Ansiklopedisi. C. IX. İstanbul.

KÚNOS, Ignácz. (1902). Sejx Sulejman Efendi's Cagataj-osmanisches Wörterbuch (Şeyh Süleyman Efendi'nin Çağatayca-Osmanlıca Sözlüğü. Budapest.

KÜÇÜKAŞÇI, Mustafa Sabri. (2002). “Kâtipé”. İslâm Ansiklopedisi, Test Yayını.

LESSİNG, F. D. (1960). Moğolca-Türkçe Sözlük. (Çev.: Günay Karaağaç). Ankara: Türk Dil Kurumu Yayınları.

LEVITSKAYA, I. (2000). Etimologiçeskiy Slovar Tyurkskih Yazıkov VI. Moskova: Akademiya Nauk.

LÜGAT-İ ÇAĞATAY VE TÜRKÎIII OSMÂNÎ (LÇ). Şeyh Süleyman Efendi Buhârî. (1298). İstanbul. MANZ, Beatrice Forbes. (1985). “The Office of Darugha Under Tamerlane”. Türklük Bilgisi Araştırmaları (Journal of Turkish Studies), S. 9, s. 59-69.

MARUFOV, Z. M. (1981). Üzbek Tilining İzohli Lugati I-II. Moskova: İzdatelstvo Russkiy Yazık.

MUHAAMMAD MAHDÎ XĀN. SANGLAX. A PERSIAN GUIDE TO THE TURKISH LANGUAGE (SENG). (1960). (Yayına Haz.: Clauson). GMS. New Series XX. London.

NECIP, Emir Necipoviç. (1995). Yeni Uygur Türkçesi Sözlüğü. (Çev. İklil Kurban), Ankara: Türk Dil Kurumu Yayınları.

ÖZGÜDENLİ, Osman Gazi. (2019). Ortaçağ'da Türkler, Moğollar, Iranlılar (Kaynaklar ve Araştırmalar). İstanbul: Ötüken Neşriyat.

ÖZYETGİN, Ayşe Melek. (1996). Altın Ordu, Kırım ve Kazan Sahasına Ait Yarlık ve Bitiklerin Dil ve Üslûp Incelemesi. Ankara: Türk Dil Kurumu Yayınları.

ÖZYETGIN, Ayşe Melek. (2004). Eski Türk Vergi Terimleri. Ankara: KÖKSAV Tengrim Türklük Bilgisi Araştırmaları Dizisi: 4. 
ÖZYETGİN, Ayşe Melek. (2005). Orta Zaman Türk Dili ve Kültürü Üzerine İncelemeler. İstanbul: Ötüken Yayınları.

RAQUETTE, Gustaf Richard. (1930). "Eıne Kaschgarısche Waqf-urkunde aus der Khodschazeit Ost-Turkestans". Lunds Universitets Årsskrift. N. F. Avd. 1. Bd. 26. Nr 2, Lund: C. W. K. Gleerup; Leipzig: Otto Harrassowitz, s.3-24.

RÄSÄNEN, Martti. (1969). Versuch eines etymologischen Wörterbuch der Türksprachen. Helsinki.

SCHURMANN, H. F. (1956). "Mongolian Tributary Practices of The Thirteenth Century". Harvard Journal of Asiatic Studies, Volume 19, İssue 3/4, s. 304-389.

SIBIR HANLIĞI KRONIKLERİ I YESIPOV KRONIĞİ (SHK I). (2020). (Çev.: Fatih Ünal ve diğerleri). İstanbul: Ötüken Neşriyat.

STEINGASS, F. (1892). A Comprehensive Persian-English Dictionary. London.

ŞEN, Serkan. (2007). Orhon, Uygur ve Karahanlı Metinlerindeki Meslekler Bağlamında Eski Türk Kültürü. Yayınlanmamış Doktora Tezi. Ondokuzmayıs Üniversitesi Sosyal Bilimler Enstitüsü.

Şiş̧MAN, Şenay Rabia. (2012). Firdevsü'l-İkbāl Giriş-Transkripsiyonlu Metin (Vr. 336a-523a). Yayınlanmamıș Doktora Tezi. Marmara Üniversitesi Türkiyat Araştırmaları Enstitüsü.

TEKIN, Talat ve diğerleri (1995).Türkmence Türkçe Sözlük. Ankara: Simurg Yayınları.

TERES, Ersin. (2009). Çağataycada Söz Yapımı. Yayınlanmamış Doktora Tezi. Yıldız Teknik Üniversitesi Sosyal Bilimler Enstitüsü.

TEZCAN, Semih. (1981). “Kutadgu Bilig Dizini Üzerine”. Belleten. C. XLV/II. S. 178. s. 23-78.

THACKSTON. (1993). Zahiruddin Muhammad Babur Mirza Bâburnâma. Chaghatay Turkish Text with Abdul-Rahim Khankhanan's Persian Translation. (Turkish Transcription, Persian Edition and English Translation by W. M. Thackston, Jr) Harvard University: Sources of Oriental Languages and Literatures.

TOGAN, A. Zeki Velidî. (1981). Umumî Türk Tarihine Giriş. İstanbul: Enderun Kitabevi. TOPARLI, Recep ve diğerleri (2003). Kıpçak Türkçesi Sözlüğü. Ankara: Türk Dil Kurumu Yayınları.

TURAN, Refik. (2002). “Türkiye Selçukluları ve Anadolu Beyliklerinde Teçkilât”. Türkler VII. Ankara: Yeni Türkiye Yayınları.

TÜRKÇE SÖZLÜK (TDK). (1996). Ankara: Türk Dil Kurumu Yayınları.

TÜRKÇE SÖZLÜK (TDK). (2005). Ankara: Türk Dil Kurumu Yayınları.

TÜRKISCHE UND MONGOLISCHE ELEMENTE IM NEUPERSISCHEN (TMEN). I-II-III-IV.

USMANOVA, M. Iu. (1964). “O termine kūrūg̀māl”. Narody Azii i Afriki. No. 4, s. 107-109.

UYGUR TILINIÑ IZAHLIK LUGITI (UTIL). (1999). Urumçi: Şinciañ Helk Neşriyati.

VÁMBÉRY, Hermann. (1867). Čagataische Sprachstudien. Leipzig.

VÁSÁRY, István. (1987). Az Arany Horda Kancellárláya. Budapest: Körösi Csoma Társaság.

VI. s. 286-322.

VLADİMİRTSOV, Boris Yakovloviç. (1929). “Moğolca Nökür”.DAN-B, s. 287-288.

WOOD, W. (2005). A Collection of Tarkhan Yarlïgs from the Khanate of Khiva. 
YAĞLI, Ali Rıza. (2014).Timurlu Devleti'nde Vezîrler Ve Vezîrlik Kurumu. Yayınlanmamış Doktora Tezi. Ankara Üniversitesi Sosyal Bilimler Enstitüsü.

YUDAHIN, K. K. (1998). Kırgız Sözlüğü I-II. (Çev.: Abdullah Taymas). Ankara: Türk Dil Kurumu Yayınları.

YÜKSEL, Musa Şamil. (2009).Timurlularda Din-Devlet İlişkisi. Ankara: Türk Tarih Kurumu Yayınları.

ZÂDE, R. (1968). İz İstorii Sredno-Aziatsko-İndiyskih Svyazey Vtoroy Polovini XIX-Naçala XX Veka, Taşkent. 